\title{
Growth and demise of Cenozoic isolated carbonate platforms: New insights from the Mozambique Channel seamounts (SW Indian Ocean)
}

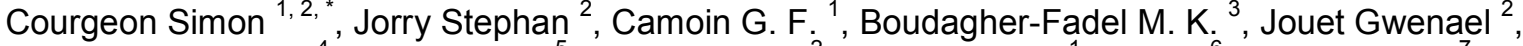 \\ Revillon Sidonie ${ }^{4}$, Bachelery P. ${ }^{5}$, Pelleter Ewan ${ }^{2}$, Borgomano J. ${ }^{1}$, Poli E. ${ }^{6}$, Droxler A. W. ${ }^{7}$
}

${ }^{1}$ Aix Marseille Univ, CNRS, IRD, CEREGE UM34, F-13545 Aix En Provence, France.

2 IFREMER, Inst Carnot Edrome, Unite Geosci Marines, F-29280 Plouzane, France.

${ }^{3}$ UCL, Earth Sci, 2 Taviton St, London WC1H OBT, England.

${ }^{4}$ IUEM, Lab Domaines Ocean, SEDISOR UMR 6538, F-29280 Plouzane, France.

${ }^{5}$ Observ Phys Globe Clermont Ferrand, Lab Magmas \& Volcans, 6 Ave Blaise Pascal, F-63178

Aubiere, France.

${ }^{6}$ CSTJF, TOTAL Explorat \& Prod, Ave Larribau, F-64000 Pau, France.

${ }^{7}$ Rice Univ, Dept Earth Sci, Houston, DC 77005 USA.

*Corresponding author : Simon Courgeon, email address : simon.courgeon@gmail.com

\begin{abstract}
:
Although long-term evolutions of isolated shallow-water carbonate platforms and demise episodes leading to guyot formation have been the subject of numerous studies during the last decades, their driving processes are still the subject of active debates. The Mozambique Channel (SW Indian Ocean) is characterized by several flat-topped seamounts ranging from $11^{\circ} \mathrm{S}$ to $21^{\circ} \mathrm{S}$ in latitudes. Based on a comprehensive geomorphologic study and on dredged samples analysis, we show that these features correspond to tropical isolated shallow-water carbonate platforms. Coupling strontium isotopy and foraminifera biostratigraphy, well-constrained chronostratigraphy results indicate that shallow-water carbonate production started in the Mozambique Channel during distinct Cenozoic periods ranging from Paleocene to Early Miocene. Our data also demonstrate that these carbonate platforms were subsequently characterized by different evolutions locally marked by tectonic and rejuvenated volcanism. While some of them kept developed until present days, forming modern carbonate systems, some others were drowned during Late Neogene and subsided to form guyots. Although different factors can be discussed, tectonic and volcanism appear as good potential triggers for demise episodes during Late Miocene-Early Pliocene times. Chronology and location of this geodynamical activity tend to emphasize influence of East African rift system until southern Mozambique Channel.
\end{abstract}




\section{Highlights}

- The flat-top seamounts of the Mozambique Channel correspond to drowned isolated shallow-water carbonate platforms. Chrono-stratigraphy indicate that these carbonate systems colonized their substratum during distinct Cenozoic periods. Major backstepping and drowning episodes were most likely triggered by geodynamical activity (tectonic and volcanism). Mozambique Channel isolated carbonate platforms recorded southern and diffuse propagation of the East African rift system.

Keywords : Carbonate platform, Drowning, Cenozoic, Mozambique Channel, East African rift system 


\section{Introduction}

Seamounts are presently defined as oceanic isolated positive topographic features either submarine, or sub-aerially exposed; their elevation is greater than $100 \mathrm{~m}$ with respect to the surrounding seafloor (Wessel et al., 2010). They are essentially volcanic edifices formed by both intrusive and eruptive processes and located in oceanic intra-plate settings over upwelling mantle plumes, on- or off-axis mid-ocean ridges or along island-arcs (Staudigel and Clague, 2010). Guyots are seamounts that have built at or above sea level and whose flat top morphology is related to wave erosion (Staudigel and Clague, 2010). The top of guyots were once at the surface because they contain evidence of fossil shallow-water biological assemblages (e.g. Camoin et al., 1998).

During their geodynamic evolution, seamounts can reach the photic zone and be colonized by shallow-water carbonate builders (e.g. Hawaiian Islands; Moore and Clague, 1992). Subsequent carbonate growth phases and seamount subsidence often lead to the formation of shallow-water isolated carbonate platforms (e.g. Pacific: Camoin et al., 1998; Wilson et al., 1998). While some of them have survived and aggraded until present-day to form modern isolated carbonate platforms (e.g. Enewetak and Pikinni atolls; Wilson et al., 1998), many of them were subsequently drowned, forming ,guyots ${ }^{\text {ee }}$ (or tablemounts; Camoin et al., 1998). Many interactive factors are considered to explain platform drowning, including (1) an abrupt increase in accommodation space outpacing carbonate growth potential and flooding the shallow-water carbonate platform below the photic zone (e.g. Schlager, 1981; Toomey et al., 2013), (2) a sharp decrease in carbonate factory production related to the degradation of environmental and climatic conditions, including subaerial exposure (e.g. Schlager, 1998) and excess of clastic and/or nutrient input (e.g. Hallock and Schlager, 1986; Camoin et al., 1998; Wilson et al., 1998; Schlager, 1999; Betzler et al., 2009), and (3) long 
term geodynamical processes, such as dynamic subsidence (e.g. Schlager, 1999; DiCaprio et al., 2010). Under stress, the surface area of the factory may often shrink and retreat towards more elevated or more protected topographies to overcome inimical environmental conditions or to keep pace with the rapid increase in accommodation space. In this situation, the drowning of the carbonate system is therefore only partial and is recorded by typical backstepping morphologies (e.g. Schlager, 2005).

The growth and demise of isolated carbonate platform are common in the geological record (e.g. Camoin et al., 1998; Wilson et al, 1998) but the processes involved on time scales of tens of millions years have been barely determined and quantified (Schlager et al, 1999). A great diversity of isolated carbonate platforms initiated and developed during Cenozoic times in the Indo-Pacific realm. In the Maldives, shallow-water carbonate production was initiated during the Eocene when shallow-water carbonate banks were formed (Aubert and Droxler, 1992). Subsequent depositional sequences were characterized by multiple carbonate growth phases separated by periods of sub-aerial exposure and drowning events driven either by eustatic sea-level changes (Purdy and Bertram, 1993; Beloposky and Droxler, 2004), bottom current activity (Lüdmann et al, 2013) or Indian Monsoon activity (Betzler et al., 2009). On Limalok guyot, occurring at $1255 \mathrm{~m}$ deep in the Pacific Ocean, the shallow-water carbonate production was initiated during the Late Paleocene on a volcanic substrate and the subsequent carbonate platform development, including periods of sub-aerial exposure, ended with its drowning during middle Eocene times (Ogg et al., 1995). Drowning events affecting late Cretaceous and early Cenozoic Pacific guyots are thought to be related to the motion of the Pacific plate that displaced shallow-water carbonate platforms into low-latitude, inimical environmental conditions (Wilson et al., 1998). The large diversity of geological processes which control the development and the drowning of Cenozoic isolated carbonate platforms illustrates the sensitivity of such systems to changes in accommodation space and 
environmental conditions on relatively long time scales. New case studies improve our understanding of shallow-water isolated carbonate systems.

The Mozambique Channel (MC) is located in the SW Indian Ocean, between the eastern African margin and Madagascar, and is characterized by several and distinct modern isolated carbonate systems forming the "Iles Eparses". In addition to these islands, lowresolution GEBCO bathymetrical grids indicate that, in the $\mathrm{MC}$, several seamounts and guyots currently occur hundreds of meters deep and are good potential analogues of classic drowned carbonate platforms. Based on new data collected during oceanographic cruises carried out in 2014, this work aims at: (1) investigating the morphology and the nature of the flanks of modern isolated systems and surrounding flat-top seamounts, (2) determining the ages of major episodes of shallow-water carbonate production and comparing them to the records of other isolated carbonate platforms from the Indo-Pacific oceans and, (3) discuss timing and processes of shallow-water carbonate platforms demise and (4) describing isolated platform geodynamic specificities and replacing the seamounts in the $\mathrm{MC}$ regional context.

\section{Geological Setting}

The MC is a broad, almost triangular, trough bounded by the Mozambique continental slope to the west and the Madagascar continental slope to the east (Fig. 1A \& 1B). The formation of the MC modern structure is related both to the break-up of the Gondwana SuperContinent which occurred during the Early Jurassic-Early Cretaceous time span, and to the relative drifting between the African and "Antarctico-Indio-Madagascarian" continental blocks (Coffin and Rabinowitz, 1987). This main structuration phase was followed by stabilization and tectoniclvolcanic stages as, for instance, during the separation of India and Antarctica from Madagascar around 84 Ma (Bassias, 1992), or more recently, with tectonic activity linked to the onset and development of the East African rift system (EARS) from the 
Oligocene up to present days (Salman and Abdula, 1995, Chorowicz, 2005, McGregor, 2015, Fig. 2).

The southward motion of Madagascar relative to Africa occurred from the Middle Jurassic to the Early Cretaceous ( $165-120 \mathrm{Ma})$ through the activity of a major transform fault known as "Davie Ridge" (DR, e.g. Coffin and Rabinowitz, 1987; Fig. 1B \& 2). This fracture zone currently corresponds to a NNW-SSE bathymetrical high of $\sim 1200 \mathrm{~km}$ in width and crossing longitudinally the MC (Fig. 1B). The DR is made of crystalline continental basement consisting of gneiss and meta-arkose, covered in places by alkaline lava, tuff and breccias and by a thin layer of Cretaceous to modern carbonate oozes (Leclaire et al., 1989; Bassias, 1992). The DR hosts several prominent submarine morphologies including, from north to south, the Saint Lazarus, Paisley, Macua and the Sakalaves seamounts whose nature and morphology remain poorly known. The south central part of the MC is characterized by a cluster of seamounts including the Hall and the Jaguar banks, the Bassas da India atoll and the Europa platform (Fig. 1B \& 1C). Although the origin of these seamounts is seemingly related to oceanic volcanism, no dredging has been carried out in that region to confirm this hypothesis. The Sakalaves and southern MC seamounts (i.e. Bassas da India, Hall and Jaguar banks) are located in a diffuse zone of the southern EARS (Kusky et al., 2010; Rovuma plate, Calais et al., 2006) between the Nubian and African plates (Fig. 2).

The northernmost part of the MC hosts the Comoro Archipelago (Fig. 1B) which is composed of four volcanic islands, from West to East: Grande Comore, Mohély, Anjouan and Mayotte. Geochronological data indicate a diachronous magmatic activity, from about $20 \mathrm{Ma}$ in Mayotte to present-day in Grande Comore (Emerick and Duncan, 1982; Michon, 2016). The origin of this archipelago is still debated and could correspond either to a deep mantle plume developing a hotspot track or, conversely, to a lithospheric deformation that reactivated transform faults and controlled the magma path (Michon, 2016). To the Northwest, the 
Glorieuses carbonate platform, the northernmost Iles Eparses, may also have developed on a volcanic edifice linked to this regional trend (Emerick and Duncan, 1982).

Nowadays, the modern isolated carbonate platforms forming the Iles Eparses are small and flat coral platforms. Covering a total of $44 \mathrm{sq}$. $\mathrm{km}$ with a highest elevation which does not exceed a few meters, the shallow-marine carbonate production typically reflects tropical neritic productivity dominated by corals, large benthic foraminifera (LBF), green algae, and molluscs (Battistini, 1976; Jorry et al., 2016; Prat et al., 2016). Last interglacial reefs form localized outcrops, which are affected by karstic processes (presence of plurimeter dissolution cavities), more or less colonized by vegetation.

\section{Material and Methods}

This work is mainly based on geophysical and geological data acquired during the 2014 PTOLEMEE and PAMELA-MOZ1 cruises onboard the RV L'Atalante, as part of the PAMELA (Passive Margin Exploration Laboratory) research project. Geological interpretations presented in this study result from the combined analysis of (1) bathymetry DEMs and associated slope maps, (2) rock samples, and (3) underwater videos.

Bathymetric data were acquired with Kongsberg EM122 (Frequency of 12kHz) and Kongsberg EM 710 (Frequency from 71 to $100 \mathrm{kHz}$ ) multibeam systems. Data were processed using CARAIBES ${ }^{\mathrm{TM}} \mathrm{v} 4.2$ software and were respectively gridded into $10 \mathrm{~m}$ and $5 \mathrm{~m}$ resolution DEMs (WGS84). Geomorphological and morphometric analysis, as well as slope maps, were processed with ArcGIS ${ }^{\mathrm{TM}}$ v10.3 using customized Mercator projections. Analysis and geological interpretation were supported by $3 \mathrm{D}$ visualization with Fledermaus ${ }^{\mathrm{TM}}$ v7 system. We also used laser bathymetry and topography (LiDAR) grids acquired between 2009 and 2011 by the Litto3D program to illustrate the modern geomorphology of the Iles Eparses. 
Underwater videos and associated pictures were collected through an interactive, submarine camera system (SCAMPI) developed by IFREMER. Viewing, analyzing and georeferencing of the videos were carried out with the $\mathrm{ADELI}^{\mathrm{TM}}$ Video v3-beta system (Ifremer@). Rock samples were collected using Niwa (DNxx - samples) and Warren (DWxx samples) dredges on flat surfaces capping the seamounts, and using rock dredges (DRxx samples) along the flanks of the seamounts.

The sedimentological interpretation combines hand sample and thin section observations. The reconstruction of carbonate depositional environments is based on the interpretation of biological assemblages and depositional textures. In our definitions of stratigraphic ranges, we primarily use the planktonic foraminifer zonal scheme described by BouDagher-Fadel (2015), which is tied to the timescale defined by Gradstein et al. (2012). We also used previous benthic and foraminiferal zonal scheme from BouDagher-Fadel (2008; 2013).

Some limestone samples were dated using Sr Isotope Stratigraphy (SIS; McArthur, 2012). To avoid bias in measured ${ }^{87} \mathrm{Sr} /{ }^{86} \mathrm{Sr}$ ratios related to post depositional processes, we adopted a sequential dissolution method using weak acetic acid prior to Sr separation using Eichrom ${ }^{\circledR}$ Sr spec Resin (Pin and Santos Zalduegui, 1997). Sr isotope compositions were measured in static mode on a Thermo TRITON at the PSO ("Pôle de Spectrométrie Océan") in Brest, France. All measured ratios were normalized to ${ }^{86} \mathrm{Sr} /{ }^{88} \mathrm{Sr}=0.1194$ and NBS987 (recommended value 0.710250). Ages were obtained using the LOWESS fit 4babacuses of McArthur (2012). Uncertainties on ages were calculated by combining the external reproducibility on measured ${ }^{87} \mathrm{Sr} /{ }^{86} \mathrm{Sr}$ ratios with uncertainties on the LOWESS fit mathematical model. Detailed values of SIS analysis are presented in additional data online (see supplementary 1 ). 


\section{Results}

\subsection{General geomorphology of the Mozambique Channel flat top seamounts}

The southern part of the MC is characterized by a SW-NE trending irregular ridge morphology supporting three flat top seamounts (Fig. 1C): the Bassas da India atoll (Fig. 3A), the Hall Bank (Fig.4A) and the Jaguar Bank (Fig. 5A). This ridge is characterized by crater and cones morphologies (Fig. 3A, 3B \& 5A) that suggest a volcanic origin.

Bassas da India (Fig. 3A) is a roughly circular atoll of about $10 \mathrm{~km}$ in diameter and 80 sq.km. The width of the reef rim averages $100 \mathrm{~m}$ and completely encloses a shallow lagoon which displays a maximum depth of $15 \mathrm{~m}$. The southern flank of the modern atoll of Bassas da India is typified by a $12 \mathrm{~km}$-wide flat top morphology (B1, Fig. 3A \& 3C). The bathymetry of this terrace ranges from $-680 \mathrm{~m}$ to $-440 \mathrm{~m}$ and is bounded by two linear escarpments, 50 to $200 \mathrm{~m}$ high, extending towards the seabed (>1500m water-depth). These escarpments are seemingly associated to major normal faults inducing important vertical offsets of terraces. A minor and shallower flat top level can be observed around 220m deep (B2, Fig. 3A \& 3C). The Hall Bank (Fig. 4) averages 90 sq.km.in areal extent and is characterized by two terraces (H1 \& H2, Fig. 4A \& 4E). The most prominent level is the shallowest one (H2) which occurs between $430 \mathrm{~m}$ and $525 \mathrm{~m}$ while the secondary and deepest one (H1) is located at $600 \mathrm{~m}$ water depth. The Jaguar Bank (Fig. 5) is located 20km west of the Hall Bank (Fig. 1C) and covers an area of 320 sq.km approximately. This seamount also exhibits an overall flat-topped morphology but is characterized by an extensive, high escarpments network (Fig. 5A). These lineaments, interpreted as normal faults, seemingly structure the overall morphology of the Jaguar Bank (Fig. 5C). They limit several tilted panels ranging from $700 \mathrm{~m}$ to $170 \mathrm{~m}$ deep on the northern margin and on the summit (southern extremity, Fig. 5A \& 5C) respectively. Bassas da India, the Hall and Jaguar banks flat-topped submarine morphologies exhibit sharp 
and abrupt margins that are commonly incised by well-developed, 0.5 to $4.5 \mathrm{~km}$ wide, steep convex bankward embayments (Fig. 3A, 4A \& 5A). The most important embayment is located on the northeastern flank of Bassas da India, and seems responsible for the "notched" morphology of the modern atoll (Fig. 3A).

The DR is typified by an overall flat top morphology of 275 sq.km known as the "Sakalaves Seamount" (Fig. 1B \& 6A) which is located at about $18^{\circ} \mathrm{S}$, in the middle of the MC. This platform morphology extends over a distance of $30 \mathrm{~km}$ from north to south and over $12 \mathrm{~km}$ from west to east, and is characterized by an elongated shape following the NNW-SSE orientation of the DR (Fig. 6A). The Sakalaves Platform is affected by numerous linear escarpments displaying the same trend, and dividing the overall morphology into multiple flat top levels ranging from $500 \mathrm{~m}$ (overall platform margin) to $335 \mathrm{~m}$ (NW and SE extremities) deep (Fig. 6A \& 6C). These escarpments exhibit typical characteristics of normal faults on bathymetrical data (Fig. 6C). To the west, a shallower level is characterized by its very rugged morphology ("ru", Fig. 6A). The abrupt slopes of the seamount are also incised by welldeveloped truncation embayment morphologies, especially along its western flank (Fig. 6A).

The Glorieuses carbonate platform (Fig. 1B \& 7A) is located about 160km northwest of Madagascar. It displays SW-NE and SE-NW extensions respectively of more than $20 \mathrm{~km}$ and of $17 \mathrm{~km}$ (Fig. 7A), and covers an area of about 230 sq.km. This platform includes an archipelago comprised of a group of islands and rocks covering 5 sq.km. The flanks of the Glorieuses platform and the nearby areas are characterized by several flat-topped morphologies and associated slope breaks (Fig. 7A) ranging from $1100 \mathrm{~m}(\mathrm{G} 1)$ to $200 \mathrm{~m}(\mathrm{G} 3)$ water depths. The NNW flank of the Glorieuses platform exhibits a drowned terrace around $750 \mathrm{~m}$ deep (G2, Fig. 7). The latter is incised by a $2.5 \mathrm{~km}$ wide embayment. All these flattopped terraces are located on a rough submarine ridge, the top of which occurs at $-1000 \mathrm{~m}$ water depth, northwest of the Glorieuses Platform. 


\subsection{Surface morphologies}

The coupled analysis of high-resolution bathymetry grids (Fig. 3B, 4B, 4C, 4D, 5B,

6B \& 7B) and underwater videos (Fig. 8) were used to determine the nature of geological features. The flanks of the drowned platforms are characterized by flat, smooth and bright rocky slabs (e.g. Hall Bank and Glorieuses, Fig. 8A \& 8B respectively) that are frequently characterized by thin and regular networks of fractures; these formations display common characteristics of carbonate rocks. Along the northeastern flank of the Hall Bank, the slope between the two main terraces (i.e.. H1 and H2, Fig. 4A) is characterized by smaller-scale, successive and parallel terrace morphologies that typify backstepped margins (Fig. 4D). Except for the Glorieuses, the MC drowned flat-topped morphologies are also characterized by well-developed closed to semi-enclosed circular depressions (e.g. Fig. 4A \& 6B) that are tens of meters to $1300 \mathrm{~m}$ wide and up to $40 \mathrm{~m}$ deep.

With the exception of the Glorieuses, the tops of the overall flat top morphologies are characterized by a great diversity of rugged and positive morphologies that seemingly intersect and partially cover the previous flat-topped topographies (Fig. 3, 4, $5 \&$ ). The very rugged flat top level located on the western side of the Sakalaves Platform ("ru.", Fig. 6B) exhibits a dense network of 50 to $2000 \mathrm{~m}$ long, and 10 to $30 \mathrm{~m}$ wide linear positive ridges. Although these ridges mostly display a regional NNW-SSE trend, they commonly form polygonal patterns and irregular heaps. Rugged morphologies and irregular reliefs are also observed on top of the Bassas da India terrace level (B1, Fig. 3A \& 3C), as well as on top of Hall (Fig. 4) and Jaguar Banks (Fig. 5). Underwater pictures made along these morphologies (Fig. 8D, 8E \& 8F) illustrated outcrops of very dark rocks associated both with rounded rocky formations resembling pillow-lavas, and dense polygonal fracturing networks that are similar 
to the tensional/contraction cracks that typically develop during submarine volcanic eruptions (e.g.Yamagishi, 1991; Chadwick et al., 2013). On top of the Jaguar Bank, some of these rugged morphologies exhibit lobate and interdigitated downslope-flowing morphologies (Fig. 5B) displaying striking similarities with submarine lobate lava flows (see Gregg and Fink, 1995). Underwater pictures taken on the western part of the Sakalaves platform top (ru level, Fig. 6A) show dark intrusions into brighter rocky outcrops (Fig. 8C), suggesting that the ridge network (Fig. 6B) corresponds to eroded volcanic dyke system.

\subsection{Dredged samples}

Rock samples collected along rough ridges (Dredges DR -04, -13, -17 \& -19, see respective locations Fig. 1C, 6A \& 7A) on which platform morphologies are established correspond to blocks of volcanic rocks (pictures available in additional data online; see supplementary 2). They are mostly composed of alkali mafic lavas (olivin basalts to nephelinites) at Bassas da India, Hall Bank, Jaguar Bank, and Sakalaves Platform. Rock samples collected on the NW ridge of the Glorieuses include encrusted trachy-andesite to trachyte lava. Polygenic pebbles that have been collected at the top of the Hall Bank (DW05, see location on Fig 4A) are composed of altered volcanic material (lavas and volcanic breccias; see additional data available online for illustrations) and limestones. These pebbles are systematically encrusted by very dark Fe-Mn oxyhydroxides layers that are up to $7 \mathrm{~mm}$ thick. Overall, rock samples collected on the upper flanks and at the top of drowned flattopped morphologies are limestones (Fig. 9, Tab. 1).

Rock sample collected along the SW flank of the Hall Bank (DR18-01, see location on Fig. 4A) corresponds to a skeletal packstone bearing large corals grains encrusted by red algae and encrusting foraminifera, many robust LBF as well as Halimeda algae (Fig. 9A, 9B \& 9C; Table 1). Such biological composition typically reflects tropical shallow-water depositional 
settings. The microfauna assemblage is characterized by Miogypsina regularia (Fig. 9C) and Lepidocyclina brouweri (Fig. 9B) which corresponds to N8a planktonic foraminifera zone (Burdigalian, BouDagher-Fadel, 2008; 2015). The isotopic strontium stratigraphy (SIS) indicates a consistent age of 16.29 +/- 0.10 Ma (Tab. 1; detailed SIS values are presented in supplementary 1 online). In addition to volcanic pebbles and undated highly altered coralgal limestones, the top of the Hall Bank (DW05; Fig. 4A) is characterized by the occurrence of a planktonic foraminifera packstone (DW5-C1, Fig. 9D, Tab. 1) typifying an outer neritic environment. It includes Sphaeroidinella dehiscens (Fig. 9D), Globorotalia tumida, Globigerinoides quadrilobatus (Fig. 9D) as well as common Globigerina spp. and Globorotalia spp; this assemblage corresponds to N18-N19 planktonic foraminifera zone defined by BouDagher-Fadel, 2015 (Late Messinian - Early Zanclean, 5.8-3.8 Ma), in agreement with the Zanclean age given by the isotopic strontium stratigraphy (i.e. 5.09 Ma, Tab. 1).

Rock sample collected along the southeastern flank of Bassas da India (DR20-01, see location on Fig. 3A) corresponds to a skeletal packstone mainly comprised of planktonic foraminifera, encrusting foraminifera and coral fragments, red algae and bivalves (Fig. 9E \& 9F, Tab. 1). The microfauna assemblage includes Orbulina suturalis (Fig. 9E), Orbulina universa, Globoquadrina dehiscens as well as Dentoglobigerina altispira and corresponds to the N9-N20a planktonic foraminifera zone (Middle Miocene - Early Pliocene). SIS gives a consistent late Miocene age of $8.48+/-0.49 \mathrm{Ma}$ (Tortonian, Tab. 1).

Dredgings carried out along the eastern flank of the Sakalaves Platform (DR13, see location on Fig. 5A) recovered volcanic rocks and limestones which correspond to a LBF-rich grainstone typified by rhodoliths and volcanic fragments (DR13-08; Fig. 9G \& 9H, Tab. 1). These limestones include Spiroclypeus vermicularis (Fig. 9C) and Cycloclypeus koolhoveni, which can be attributed to the P18-P19 foraminifera zones (BouDagher-Fadel, 2013; 2015, 
Rupelian, 33.9-30.3 Ma, Tab. 1). The obtained SIS age is of $33.11+/-0.14$ Ma (Early Oligocene, Rupelian) for DR13-08 and is therefore consistent with biostratigraphic data. Rock samples recovered from the top of the Sakalaves Platform (DW04, see location on Fig.6A) are comprised of coralgal boundstone (DW04-01, Fig. 9I) and outer shelf planktonic foraminifera packstone (DW04-02a, Fig. 9J). The occurrence of Cycloclypeus postinornatus and Cycloclypeus carpenteri in DW04-01 indicates the N14 to N21 shallow benthic zones (BouDagher-Fadel, 2008; 2015, Late Miocene-Pliocene, 11.6-1.8 Ma). SIS gives an age of 8.80 +/- 0.35 Ma (Tortonian) for DW04-01 (Fig. 9). DW04-02a includes Sphaeroidinella subdehiscens, Globoquadrina sp. and Orbulina universa (Fig. 9J) and is associated to N19N20 planktonic foraminifera zone (Zanclean; BouDagher-Fadel, 2015; Tab. 1). For the latter, no SIS age is available.

Finally, rock samples collected on the flat top morphology located NW of the Glorieuses (DN01, see location on Fig. 6J) correspond to coralgal boundstones with pockets of Discocyclinid LBF packstones (Fig. 9K \& 9L). The relevant assemblage, characteristic of a tropical shallow-water depositional environment, includes Discocyclina sella (Fig. 9L) and Daviesina sp. and coincides with the P3-P5a foraminifera zone (BouDagher-Fadel, 2008, Paleocene). SIS analysis on DN01-01 provides three potential ages of $67.11+/-0.27 \mathrm{Ma}$, $61.52+/-1.80 \mathrm{Ma}$ and $33.89+/-0.15 \mathrm{Ma}$. The foraminifera assemblage indicates that this limestone is Selandian to Thanetian in age (Paleocene), thus suggesting that the correct SIS age is of $61.52+/-1.80 \mathrm{Ma}$ (Tab. 1).

\section{Discussion}

\subsection{Origin of Mozambique Channel flat top seamounts}

While most of flat top seamounts are currently drowned at hundreds of meters deep (i.e below the photic zone), the MC submarine plateaus and terraces display typical 
geomorphological features of shallow-water carbonate platforms. Their morphologies are characterized by successive very steep margins delineating distinct terraces levels (Fig. 3, 4, $5,6 \& 7)$ that are interpreted as resulting from different phases of carbonate platform development and backstepping. The observed very steep margins, characterized by bright rocky slabs (Fig. 8A \& 8B), are very reminiscent of shallow-water carbonate flanks that typically accumulate along tropical carbonate platforms. The biological assemblages that characterize the limestones samples recovered along $\mathrm{MC}$ carbonate platforms are mainly composed of hermatypic corals, coralline red algae, green algae (Halimeda) and LBF (Fig. 9), thus confirming a tropical shallow-water depositional environment. The combination of biostratigraphic and strontium isotopic data demonstrates that MC shallow-water carbonate platforms colonized their volcanic substrates during distinct Cenozoic time windows, ranging from the Paleocene to the Early Miocene.

The rounded depressions (Fig. 4A \& 6B) observed on top of the drowned terraces of the south $\mathrm{MC}$ and Sakalaves flat-top seamounts could be related to explosive events or gravity collapses associated to volcanic activity (e.g. Chadwick et al., 2013). They might also correspond to karst pits caused by carbonate dissolution processes and associated collapses (e.g. Grigg et al., 2002; Guidry et al., 2007) into a carbonate platform which underwent (a) long period(s) of subaerial exposure. As observed along numerous ancient and modern carbonate platforms margins (e.g. Bahamas Archipelago, Jo et al., 2015), the MC drowned platform margins are incised by well-developed steep convex-bankward embayments (mfs, Fig 3A, 4A, 5A, 6A \& 7B). These truncation features, also called "scalloped margins" (Mullins and Hine, 1989) are interpreted as erosional features resulting from catastrophic large-scale margin failures usually induced by earthquake shocks in tectonically active areas, and by dissolution processes and lor deep water currents in stable regions (Mullins and Hine, 1989; Jo et al., 2015). 


\subsection{Long-term (Paleocene to Present) evolution of the Glorieuses carbonate} platform

In the northern part of the MC channel, the Glorieuses volcanic ridge (Fig. 7A) was colonized by an isolated carbonate system during the Paleocene (Fig. 10) at the latest, as indicated by the Selandian to Thanetian age (Tab. 1) of its second terrace level (G2, Fig. 7B) which crops out at $750 \mathrm{~m}$ deep. The coralgal limestones that are associated with abundant Discocyclinid LBF suggest that this drowned terrace developed in a shallow-water depositional environment. Although Early Paleogene platform carbonates are often poorly preserved and $\backslash$ r inaccessible (Baceta et al., 2005), LBF-rich reef carbonates have been well documented in Paleocene shallow-water formations (e.g. Bryan, 1991; Scheibner and Speijer, 2008b). The occurrence of a carbonate terrace (G1, Fig 7A), at approximately 1100m deep, suggests that carbonate production started even before the Late Paleocene, i.e. most likely during Early Paleocene or Late Cretaceous. Overall, the distinct terrace levels (G1, G2 \& G3; Fig. 7) observed along the flanks of the Glorieuses carbonate platform are interpreted as resulting from successive development and backstepping episodes, before the initiation of modern shallow-water carbonate systems.

The drowning of the 750m deep coralgal Paleocene terrace (G2, Fig. 7B) could be associated with the major long-term climatic warming of the Paleocene-Eocene transition during which many Tethyan coral reef systems declined (Scheibner and Speijer, 2008a,b). Furthermore, the narrowness of the volcanic ridge which is located NW of the Glorieuses platform potentially deprived the carbonate builders of an appropriate large substrate on which the platform could have backstepped. Despite the occurrence of successive terraces (Fig. 7), the long-term evolution of the Glorieuses carbonate platform appears relatively continuous at the Cenozoic time scale. The development of shallow-water carbonate 
platforms during the Cenozoic is quite common in the Western Indian Ocean, as indicated for instance at de Saya de Malha and Nazareth Banks (Mascareign Ridge), where exploration wells SM1 and NB-1 (Texaco Inc.) have penetrated Late Paleocene to Pliocene shallow-water carbonate platform limestones (Kamen-Kaye and Meyerhoff, 1980).

\subsection{Oligo-Miocene growth of south MC and Sakalaves shallow-water carbonate} platforms

The shallow-water carbonate production on the Sakalaves Platform, presently drowned at $335 \mathrm{~m}$ deep, was initiated on the DR during the Oligocene (Tab. 1, Fig. 10). The occurrence of many volcanic fragments (Fig. 9G) into the skeletal packstone recovered along the western flank of the Sakalaves platform suggests the presence of nearby volcanic reliefs during carbonate deposition, confirming that the colonization occurred during Rupelian time. The LBF and red algae-rich carbonate assemblage that characterizes the relevant carbonates (Fig. 9G \& 9H, Tab. 1) is quite similar to that of other Oligocene shallow-water carbonate platforms, such as the Lepidocyclina limestones that have been described in early Oligocene deposits of the Cayman Brac isolated carbonate bank (Caribbean, Jones and Hunter, 1994). Drilling operations carried out on the Kerendan platform (Oligocene, Indonesia) also reported packstones that are rich in large benthic foraminifera and fragments of coralline algae (Saller and Vijaya, 2002). The Sakalaves carbonate platform most likely continued its development during Miocene times (Fig. 10) until the deposition of Late Miocene (Tortonian) coralgal frameworks (Fig. 6A \& 9I). This result is consistent with a previous study reporting Miocene limestones on top of the platform (Leclaire et al., 1989). The presence of Zanclean outer shelf packstones suggests that the drowning of the Sakalaves shallow-water carbonate platform occurred during Late Miocene to Early Pliocene times (Fig. 10) 
In the South MC, the analysis of limestone samples collected along the southwestern flank of the Hall Bank (Tab. 1) suggests that carbonate production started at the latest during the Early Miocene (Fig. 10). Although no Early Miocene carbonate samples have been collected along the flanks of Bassas da India and of the Jaguar Bank, these features are located on the same volcanic ridge and presently occur at similar depths (i.e. $600-800 \mathrm{~m}$, Fig. 3, $4 \& 5$ ), thus suggesting that they may have appeared during the same period. The abundance of encrusted coral fragments, robust large benthic foraminifera and Halimeda algae (DR18-01 \& DR20-01; Tab. 1) indicates that the South MC Miocene limestones were deposited in shallow-water carbonate environments. Similar Miocene carbonate assemblages have been commonly reported in the Indo-Pacific realm and were often associated to reef systems (e.g. Australia, Betzler and Chapronière, 1993; Bornéo, Wilson, 2005; Indonesia, Novak et al., 2013). During its evolution, the Hall Bank underwent a major backstepping episode which shifted carbonate production from $\mathrm{H} 1$ to $\mathrm{H} 2$ terrace (Fig. 4A \& 4D). The demise of shallow-water carbonate sedimentation on the Hall Bank is marked by the deposition of outer shelf carbonates during early Pliocene times (Tab. 1, Fig. 10). Conversely, in Bassas da India, aggradation processes continued until present days to form a modern atoll. The Fe-Mn crusts observed on pebbles collected on top of the Hall Bank have been commonly reported on top of drowned shallow-water carbonate platforms (e.g. Pacific guyots, Bogdanov et al., 1995; Camoin et al., 1998) where they have been interpreted as resulting from a slow precipitation onto hard substrates in areas swept by strong bottom current (e.g. Mangini et al., 1986).

\subsection{Late Miocene - Early Pliocene drowning phases: tectonic and rejuvenated} volcanism as major triggers? 

of widespread faults and fracturing networks on tops of drowned carbonate terraces suggest that geodynamic activity could be involved in shallow-water carbonate platforms demises during Late Miocene to Early Pliocene times. Morphological analysis as well as underwater pictures and dredge samples display many evidences of subaqueous extrusive volcanism (e.g. pillow lavas and lobate lava flow, Fig. 4C, 5B, 8D, 8E \& 8F) but also of intrusive volcanism especially typified by dyke morphologies as observed along the Sakalaves Platform (Fig. 6B \& 8C). Relevant eruptive phases brought volcanic material (e.g. lava flow, volcanoclasts) and significant environmental changes (e.g. water transparency, water temperature) that likely stressed and smothered shallow-dwelling carbonate producers. In parallel, The MC drowned carbonate platforms are affected by widespread and extensive faults and fracturing networks which display extensional deformation patterns such as frequent high-offset normal faults (e.g. Fig. 3, 5A, 5C \& 6). In this context, drowning of the $\mathrm{MC}$ shallow-water carbonate platforms could be related to extensional deformation and rapid pulses of tectonic subsidence outpacing carbonate accumulation rates. For instance, the occurrence of two high-offsets 445 normal faults delimiting Bassas da India first terrace (B1, Fig. 3A) suggests that tectonic 446 movements were involved in the major backstepping phase through the sudden drowning of 447 shallow-water carbonate producers below the photic zone. The continuous development of 448 Bassas da India isolated carbonate systems after late Miocene-Pliocene drowning events 449 suggests the occurrence of topographic highs, such as tectonically raised area, that 450 subsequently allowed the backstepping of the shallow-water carbonate factory. Volcanic 451 morphologies (e.g. lava deltas, Hawaii; Puga-Bernabéu et al., 2016) may be also colonized by 452 shallow-water carbonate systems during backstepping processes in response to a rapid 453 increase in accommodation space or to environmental deterioration. Along Tonasa carbonate 454 platform (Sulawesi, Indonesia), Wilson (2000) also described shallow-water carbonate 
455

456 activity.

457 Environmental disturbances (e.g. nutrient input, paleo-climatic and -oceanographic changes)

458 are frequently invoked to explain the demise of shallow-water carbonate platform and also

459 have to be discussed. Dredge samples analysis suggest that demise of the Sakalaves Platform

460 and drowning episodes of south MC carbonate platforms took place during late Miocene to

461 early Pliocene times (Fig. 10). In the Indo-Pacific realm, several drowning episodes induced

462 by environmental deterioration have reported during the same Neogene time span. On the

463 Marion Plateau (Australia), cooling and re-organization of ocean circulation triggered during

464 Late Miocene, successive drowning events of the carbonate platform (Eberli et al., 2010).

465 Along Maldives carbonate platform, Betzler et al. (2009) proposed that late Miocene-Early

466 Pliocene partial drowning of the platform is linked to onset and intensification of the

467 Monsoon trough injection of nutrient into shallow-water. Coeval drowning episodes in the

468 Indo-Pacific realm suggest that environmental conditions deterioration linked to paleo-

469 climatic and paleo-oceanographic reorganization could also be involved in Late Neogene

470 demise of the MC shallow-water carbonate platforms. Finally, the rounded depressions

471 observed on Hall Bank top and that potentially correspond to karst pits, might suggest

472 extended periods of subaerial exposure which are potential triggers of major drowning events

473 (e.g. Schlager et al., 1998).

\section{$474 \quad$ 5.5. Geodynamical implications} 477 shallow-water carbonate producers, and (2) the occurrence of such a substrate in the euphotic 478
Two primary conditions are required for the initiation and development of a tropical isolated carbonate system: (1) the existence of a hard substrate available for the settlement of zone. This study demonstrated that the MC carbonate platforms developed on irregular and 
isolated volcanic reliefs (Fig. 1C, 3, $5 \& 7$; rock samples pictures available on supplementary 2 online). In the Glorieuses, the record of a Selandian to Thanetian terrace (G2, Fig. 7 \& Tab. 1) implies that the volcanic event that was responsible for the formation of the seamount occurred before the Late Paleocene (Fig. 10). This volcanic phase could be related to the interaction between Madagascar and the Marion Hotspot (Meert and Tamart, 2006) and to the coeval breakup of Madagascar and Greater India during late Cretaceous times (Storey et al., 1995). The Glorieuses seamount may belong to a SE-NW volcanic axis running from northwestern Madagascar coast towards Aldabra Atoll and encompassing the Leven Bank (Fig. 2). The minimum Paleocene age of the Glorieuses seamount seemingly excludes its links with the volcanic activity recorded in the Comoros Archipelago and that has been recently interpreted as resulting from a lithospheric deformation in relation to the East African Rifting during late Cenozoic times (Michon, 2016, Bachélery and Hémond, 2016). With the exception of the G2 terrace, the Glorieuses platform does not exhibit evidences of major drowning events during its Cenozoic development. In parallel, no evidence of tectonic or of any renewed volcanic activity has been observed along its flank and in the nearby areas suggesting that the Glorieuses carbonate platform has evolved in an overall stable geodynamical setting since Early Paleogene times. Taking into account that Paleocene eustatic sea level was approximately 50m above present day sea level (Miller et al., 2005), the average subsidence of the Glorieuses seamount since the Paleocene is estimated between 10 and $15 \mathrm{~m} / \mathrm{Myr}$.

Based on volcanic substrates, south MC and Sakalaves drowned carbonate platforms display striking evidences of volcanic and tectonic activities during and lor after carbonate platform development. In the southern $\mathrm{MC}$, the eruptive phases responsible for the development of a volcanic ridge (Fig. 1C) probably occurred during Oligocene to early Miocene times, before its colonization by isolated carbonate systems and subsequent 
development of carbonate platforms during the Miocene (Fig. 10). A phase of rejuvenated volcanism and tectonic deformation took place in the Middle Miocene to Pliocene time span, and possibly until the Pleistocene (Fig. 10). Along the DR, on the Sakalaves Platform, the combination of geomorphological analysis and the dating of carbonate samples also demonstrate that tectonic deformation and volcanism occurred from the Oligocene to the present days. The Sakalaves Platform, which is affected by a dense fault network parallel to NNW-SSE DR trend, is located in a seismically active area which seemingly corresponds to an extension of the EARS offshore branch (McGregor, 2015; Fig. 2). The large margin failure scars incising carbonate platform slopes (Fig. 3, 4, $5 \&$ 6) could also indicate a sustained tectonic activity (e.g. Mullins and Hine, 1989) along MC Cenozoic carbonate platforms. The volcanic and extensional tectonic phases that have been identified along the Sakalaves Platform and in the southern Mozambique Channel are coeval with the activity of the EARS during Cenozoic times (McGregor, 2015), i.e. from Oligocene to present-day. Moreover, the Sakalaves and southern MC carbonate platforms are located in a diffuse zone of the EARS (Kusky, 2010) between Nubian and Somalian plates (Fig. 2). This area has been also interpreted as another plate (Rovuma plate; Calais et al., 2006) and is characterized by scattered but significant modern seismicity (Fig. 2). The formation of the volcanic basement which forms the substrate of some MC carbonate platforms, as well as the extensional tectonic and rejuvenated volcanism observed at the top of the platforms are thus interpreted as links to EARS development and tend to confirm its southern diffuse propagation (Kusky, 2010). This example illustrates again that isolated shallow-water carbonate production has the ability to record regional-scale geodynamic activity but also, conversely, that geodynamical processes appear as major control parameters of tens of millions year shallow-water carbonate platform evolution (e.g. Wilson, 2000; Yubo et al., 2011).

\section{Conclusions}


The main results of this study can be summarized as follow:

(1) The flat top and drowned seamounts of the Mozambique Channel correspond to ancient tropical and isolated shallow-water carbonate platforms that initially settled on volcanic substrates.

(2) The Mozambique Channel isolated carbonate platforms, located in different geodynamical settings, set on during distinct Cenozoic periods ranging from Paleocene to Early Miocene. These chronostratigraphic results are consistent with important phases of shallow-water carbonate platform growth in the Indo-Pacific realm during the Cenozoic.

(3) The Mozambique Channel isolated carbonate platforms underwent distinct polyphase evolutions that locally comprised tectonic deformation, volcanism and major backstepping and drowning phases. Although the origin of demise episodes remain unclear, tectonic and rejuvenated volcanism appear as most likely triggers. In parallel, Glorieuses and Bassas da India shallow-water carbonate platforms survived and kept on developing until present-day.

(4) Along the Sakalaves and the south Mozambique Channel carbonate platforms, Cenozoic tectonic and volcanic activity is coeval and seems spatially linked to the development and the propagation of the Eastern African rift system. The Paleocene onset of shallow-water carbonate production at the Glorieuses carbonate platforms suggest Late Mesozoic volcanism north of Madagascar, decoupled from more recent EARS activity.

Processes controlling shallow-water carbonate platform growth and demise on time scales of tens of millions year periods are actively discussed but they remain poorly mastered. The MC, representing a new promising area to study shallow-water carbonate platforms growth and drowning events, suffers from lack of coring data to quantify numerous crucial parameters such as growth rates or high frequencies environmental fluctuations. In this 
553

context, drilling operations along the MC channels flat-top seamounts would offer an outstanding opportunity to improve our understanding of isolated shallow-water carbonate platforms systems.

\section{Acknowledgements}

We are grateful to Captain, Officers, and crew members of the 2014 PTOLEMEE (http://dx.doi.org/10.17600/14000900)

and

PAMELA-MOZ1

(http://dx.doi.org/10.17600/14001000) cruises onboard the R/V L'Atalante for their technical support in recovering high-quality dataset. We thank Stephane Bodin and an anonymous reviewer for insightful comments on the previous version of this manuscript. The authors warmly thank Philippe Fernagu (Ifremer) for the preparation of thin-sections and Charline Guérin, Arnaud Gaillot and Delphine Pierre for bathymetry grids processing. The oceanographic expeditions PTOLEMEE and PAMELA-MOZ1 as well as the Mozambique 2014 study were co-funded by TOTAL and IFREMER as part of the PAMELA (Passive Margin Exploration Laboratory) scientific project.

\section{References}

Aubert, O., Droxler, A.W., 1992. General Cenozoic evolution of the Maldives carbonate system (equatorial Indian Ocean). Bulletin Des Centres de Recherches Exploration-Production Elf-Aquitaine 16, 113-136.

Baceta, J.I., Pujatte, V., Bernaola, G., 2005. Paleocene coralgal reefs of the western Pyrenean basin, northern Spain: New evidences supporting an earliest Paleogene recovery of reefal ecosystems. Palaeogeography, Palaeoclimatology, Palaeoecology 224, 117-143

Bachèlery, P., Hémond, C., 2016. Geochemical and Petrological Aspects of Karthala Volcano, in Active volcanoes of the Soutwest Indian Ocean, in Active volcanoes of the world,Bachèlery, P.,Lénat, J.-F., Di Muro, A.,Michon, L. (Eds.), 2016, Springer-Verlag, Chapter 23, 367-384

Bassias, Y., 1992. Petrological and geochemical investigation of rocks from the Davie Fracture Zone (Mozambique Channel) and some tectonic implications. Journal of African Earth Sciences 15, 321-339.

Battistini R., Gayet J., Jouannic C., Labracherie M., Peypouquet J.P., Pujol C., Pujos-Lamy A., Turon J.L. (1976) Etude des sédiments et de la microfaune des îles Glorieuses (Canal du Mozambique). Cah. ORSTOM Ser. Géol. 2, 147-171. 
Belopolsky, A.V., Droxler, A.W., 2004. Seismic expressions and interpretations of carbonate sequences: The Maldives carbonate platform, equatorial Indian Ocean. American Association of Petroleum Geologists Studies in Geology 49, 46 p.

Betzler, C., Brachert, T.C., Kroon, D., 1995. Role of climate in partial drowning of the Queensland Plateau carbonate platform (northeastern Australia). Marine Geology 123, 11-32.

Betzler, C., Chaproniere, G.C.H., 1993. Paleogene and Neogene larger foraminifers from the Queensland Plateau: biostratigr phy and environmental significance. Proceedinds of Ocean Drilling Programs, Scientific results 133 , p 51-66.

Betzler, C., Hübscher C., Lindhorst, S., Reijmer, J.J.G., Römer, M., Droxler, A.W., Fürstenau, J., Lüdmann, T., 2009. Monsoon-induced partial carbonate platform drowning (Maldives, Indian Ocean). Geology 39, 867-870.

Bogdanov, Y.A., Bogdanova, O.Y., Dubinin, A.V., Gorand, A., Gorshkov, A.I., Gurvich, E.G., Isaeva, A.B., Ivanov, G.V., Jansa, L.F., Monaco, A., 1995. Composition of ferromanganese crusts and nodules at nortwestern pacific guyots and geologic and paleooceanographic considerations, in: Haggerty, J.A., Premoli Silva, I., Rack, F., and McNutt, M.K. (Eds.), Proceedings of the Ocean Drilling Program, Scientific Results 144, 745-768.

BouDagher-Fadel, M.K., 2015. Biostratigraphic and Geological Significance of Planktonic Foraminifera, London, UCL Press, 298 p.

BouDagher-Fadel, M.K., 2013. Diagnostic First and Last Occurrences of Mesozoic and Cenozoic Planktonic Foraminifera. Professional Papers Series, 1-4.

BouDagher-Fadel, M.K., 2008. Evolution and Geological Significance of Larger Benthic Foraminifera. Developments in Palaeontology and Stratigraphy 21, 1-548.

Bryan, J. R. 1991. A Paleocene coral-algal-sponge reef from southwestern Alabama and the ecology of Early Tertiary reefs. Lethaia $24,423-438$.

Calais, E., Ebinger, C., Hartnady, C., Nocquet, J.M., 2006. Kinematics of the eastern African Rift from GPS and earthquakke slip vector data. Geological society of London special publications 259, 9-22.

Camoin, G.F., Arnaud-Vanneau, A., Bergersen, D.D., Enos, P., Ebren, P., 1998. Development and demise of mid-oceanic carbonate platforms, WodejabatoGuyot (NW Pacific). International Association of Sedimentologists Special Publication 25, 39-67.

Chadwick Jr., W.W., Clague, D.A., Embley, R.W., Perfit, M.R., Butterfield, D.A., Caress, D.W., Paduan, J.B., Martin, J.F., Sasnett, P., Merle, S.G., Bobbitt, A.M., 2013. The 1998 eruption of Axial Seamount: New insight on submarine lava flow emplacement from high-resolution mapping. Geochemistry, Geophysics, Geosystems $14,3939-3968$.

Chorowicz, J., 2005. The East African rift system. Journal of African Earth Sciences 43, 379-410.

Coffin, M. F., Rabinowitz, P. D., 1987. Reconstruction of Madagascar and Africa: evidence from the Davies Fracture Zone and Western Somali Basin. Journal of Geophysical Research 92, 9385-9406.

DiCaprio, L., Dietmar Müller, R., Gurnis, M., 2010. A dynamic process for drowning carbonate reefs on the noertheastern Australian margin. Geology 38, 11-14.

Eberli, G.P., Anselmetti, F.S., Isern, A.R. \& Delius, H., 2010. Timing of changes in sea-level and currents along Miocene Platforms on the Marion Plateau, Australia. In: Cenozoic Carbonate Systems of Australia (Ed. by Morgan W.A., George A.D., Harris P.M., J.A. Kupecz \& J.F. Sarg), SEPM Spec. Publ. 95, 219-242. SEPM, Tulsa, OK.

Emerick, C.M., Duncan, R.A., 1982. Age progressive volcanism in the Comores Archipelago, western Indian Ocean and implications for Somali plate tectonics. Earth and Planetary Science Letters 60, 415-428.

Gradstein, F.M., Ogg, J.G., Hilgen, F.J., 2012. On the Geologic Time Scale. Newsletters on Stratigraphy 45, 171-188. 
Gregg, T.K.P., Fink, J.H., 1995. Quantification of submarine lava-flow morphology trough analog experiments. Geology 23, 73-76.

Grigg, R.W., Grossman, E.E., Earle, S.A., Gittings, S.R., Lott, D., McDonough, J., 2002. Drowned reefs and antecedent karst topography, Au'au Channel, S.E. Hawaiian Islands. Coral Reefs 21, 73-82.

Guidry, S.A., Grasmueck, M., Carpenter, D.G., Gombos, Jr., A.M., Bachtel, S.L., Viggiano, D.A., 2007. Karst and early fracture networks in carbonates, turks and Caicos islands, British West Indies. Journal of Sedimentary Reasearch 77, 508-524.

Hallock, P., and Schlager, W, 1986. Nutrient excess and the demise of coral reefs and carbonate platforms. Palaios 1, 389-398.

Jo, A., Eberli, G.P., Grasmueck, M., 2015. Margin collapse and slope failure along southwestern Great Bahama Bank. Sedimentary Geology 317, 43-52. Facies 30, 25-50.

Jones, B., Hunter, I.G., 1994. Evolution of an isolated carbonate bank during Oligocene, Miocene and Pliocene times, Cayman Brac, British Western Indies.

Jorry, S.J., Camoin, G.F., Jouet, G., Le Roy, P., Vella, C., Courgeon, S., Prat, S., Paumard, V., Boulle, J., Caline, B. and Borgomano., J., 2016. Modern sediments and Pleistocene reefs from isolated carbonate platforms (Iles Eparses, SW Indian Ocean): A preliminary study. ActaOecologica 72, 129-143.

Kamen-Kaye, M., Meyerhoff, A.A., 1980, Petroleum geology of the Mascarene Ridge, Western Indian Ocean. Journal of Petroleum Geology 3, 123-138.

Kusky, T.M., Toraman, E., Raharimahefa, T., Rasoazanamparany, C., 2010. Active tectonics of the AlaotraAnkay Graben system, Madagscar: Possible extension of Somalian-African diffuse plate boundary. Gondwana Reasearch 18, 274-294.

Leclaire, L., Bassias, Y., Clocchiatti, M. and Segoufin, J., 1989. La formation de la ride de Davie. Approche stratigraphique et géodynamique. Comptes Rendus de l"Académie des Sciences de Paris 308, 1077-1082.

Lüdmann, T., Kalvelage, C., Betzler, C., Fürstenau, J., Hübscher C., 2013. The Maldives, a giant isolated carbonate platform dominated by bottom currents. Marine and Petroleum Geology 43, 326-340.

Mangini, A., Halbach, P., Puteanus, D., Segl, M., 1987 Chemistry and growth history of central Pacific Mn crusts and their economic importance, Marine Minerals, 205-220.

McArthur, J. M., Howarth,R. J. et al., 2012. Chapter 7 - Strontium Isotope Stratigraphy. The Geologic Time Scale 2012, Boston, Elsevier, 127-144.

McGregor, D., 2015. History of the development of the East African Rift System: A series of interpreted maps through time. Journal of African Earth Sciences 101, 232-252.

Moore, J.G., Clague, D.A., 1992. Volcano growth and evolution of the island of Hawaii. Geological Society of America Bulletin 104, 1471-1484.

Michon, L., 2016. The volcanism of the Comoros Archipelago integrated at a regional Scale, in: Bachèlery, P., Lénat, J.-F., Di Muro, A., Michon, L. . (Eds.), Active volcanoes of the Soutwest Indian Ocean. Springer-Verlag, the Netherlands 333-344.

Miller, K.G., Kominz, M.A., Browning, J.V., Wright, J.D., Mountain, G.S., Katz, M.E., Sugarman, P.J., Cramer, B.S., Christie-Blick, N., \&Pekar, S.F., 2005. The phanerozoic record of global sea-level change. Science 310, 1293-1298.

Meert, J.G., Tamrat, E., 2006. Paleomagnetic evidence for a stationary Marion hotspot: Additional paleomagnetic data from Madagascar. Gondwana Research 10, 340-348.

Mullins, H.T., Hine, A.C., 1989, Scalloped bankmargins; beginning of the end for carbonate platforms?. Geology 17, 30-33. 
Novak, V., Santodomingo, N., Rösler, A., Di Martino, E., Braga, J,.C., Taylor, P.D., Renema, W., 2013. Environmental reconstruction of a late Burdigalian (Miocene) patch reef in deltaic deposits (East Kalimantan, Indonesia). Palaeogeography, Palaeoclimatology, Palaeoecology 374, 110-122

Ogg, J.G., Camoi, G.F., Arnaud Vanneau, A., 1995. LimalokGuyot: depositional history of the carbonate platform from downhole logs at site 871 (lagoon), in: Haggerty, J.A., Premoli Silva, I., Rack, F., and McNutt, M.K. (Eds.), Proceedings of the Ocean Drilling Program, Scientific Result 144, 233-253.

Pin, C., Santos Zalduegui, J.F., 1997. Sequential separation of light rare-earth elements, thorium and uranium by miniaturized extraction chromatography: Application to isotopic analyses of silicate rocks. Analytica Chimica Acta 339, 79-89.

Prat S., Jorry S.J., Jouet G., Camoin G.F., Vella C., Le Roy P., Caline B., Boichard R., Pastol Y. (2016) Geomorphology and sedimentology of a modern isolated carbonate platform: The glorieuses archipelago, SW Indian Ocean. Marine Geology, in press

Puga-Bernabéu, A., Webster, J.M., Braga, J.C., Clague, D.A., Dutton, A., Eggins, S., Fallon, S., Jacobsen, G., Paduan, J.B., Potts, D.C., 2016. Morphology and evolution of drowned carbonate terraces during the last two interglacial cycles, off Hilo, NE Hawaii. Marine Geology 371, 57-81.

Purdy, E.G., Bertram, G.T., 1993. Carbonate concepts from the Maldives, Indian Ocean: American Association of Petroleum Geologists Studies in Geology, v. 34, 56 p..

Saller, A.H., Vijaya, S., 2002. Depositional and diagenetic history of the Keredan carbonate platform, Oligocene, Central Kalimantan, Indonesia. Journal of Petroleum Geology 25, 123-150.

Salman, G., Abdula, I., 1995. Development of the Mozambique and Ruvuma sedimentary basins, offshore Mozambique, Sedimentary Geology 96, 7-41.

Scheibner, C., Speijer, R.P., 2008a. Decline of coral reefs during late Paleocene to early Eocene global warming. eEarth 3, 19-26.

Scheibner, C., Speijer, R.P., 2008b. Late Paleocene-early Eocene Tethyan carbonate platform evolution - A response to long- and short-term paleoclimatic change, Earth-Science Reviews 90, 71-102.

Schlager, W., 1981. The paradox of drowned reefs and carbonate platforms. Geological Society of America Bulletin 92, 197-211.

Schlager, W., 1998. Exposure, drowning and Sequence Boundaries on Carbonate platforms, in Reefs and Carbonate Platforms in the Pacific and Indian Oceans, Camoin, G.F., Davies, P.J. (Eds.), Special Pulications of Internationnal Association of Sedimentologists 25, 3-21.

Schlager, W., 1999. Scaling of sedimentation rates and drowning of reefs and carbonate platforms. Geology 27 , p. $183-186$

Schlager, W., 2005. Carbonate Sedimentology and Sequence Stratigraphy. SEPM Concepts in Sedimentology and Paleontology, Series no. 8, 200 p.

Staudigel, H., Clague, D.A., 2010. The geological history of deep-sea volcanoes: Biosphere, hydrosphere, and lithosphere interactions. Oceanography 23, 58-71.

Toomey, M., Ashton, A.D., Perron, J.T., 2013. Profiles of ocean islands coral reefs controlled by sea-level history and carbonate accumulation rates. Geology 41, 731-734.

Wessel, P., Sandwell, D.T., Kim, S.S., 2010. The global seamount census, Oceanography 23, 24-33.

Wilson, M.E.J., 2000. Tectonic and volcanic influences on the development and Diachronous termination of a Tertiary tropical carbonate platform. Journal of Sedimentary Research 70, 310-324.

Wilson, M.E.J., 2005. Development of equatorial delta-front patch reefs during the Neogene, Borneo. Journal of Sedimentary Reasearch 75, 114-133. 
Wilson, P.A., Jenkyns, H.C., Elderfield, H., Larson, R.L., 1998. The paradox of drowned carbonate platforms and the origin of Cretaceous Pacific guyots. Nature 392, 889- 894.

Yamagishi, H., 1991. Morphological and sedimentological characteristics of the Neogene submarine coherent lavas and hyaloclastites in Southwest Hokkaido, Japan, Sedimentary Geology 74, 5-23.

Yubo, M., Shiguo, W., Fuliang, L., Dongdong, D., Qiliang, S., Yintao, L., Mingfeng, G., 2011. Seismic characteristics and development of the Xisha carbonate platforms, northern margin of the South China Sea. Journal of Asian Earth Sciences 40, 770-783.

\section{Captions}

Figure1: (A) Location of the Mozambique Channel in the Western Indian Ocean (B) General physiography of the Mozambique Channel, bathymetry grid comes from GEBCO (100m resolution, 2008). Studied seamounts are in bold.(C) Detailed physiography of Southern Mozambique Channel seamounts, red line and lettering correspond to dredging. Isobaths have been computed every $500 \mathrm{~m}$ water depth.

Figure2: The Mozambique Channel and the East African rift system. Glo means Glorieuses Platform. The Sakalaves Platform (Sa) and south $\mathrm{MC}$ carbonate platform $(\mathrm{Ba})$ are located in a diffuse zone of the EARS (Kusky et al., 2010). This area between western and southeastern branches is also interpreted as another plate: the Rovuma plate (Calais et al., 2006). The two white lines drawn north of Madagascar represent an hypothetical Late Mesozoic volcanic alignment (see details in the text). Elevation/bathymetry grid comes from GEBCO (100m resolution).

Figure3: (A) Geomorphology of Bassas da India Atoll seamount (see location on figure 1B \& 1C). Green italic lettering corresponds to the nomenclature for successive flat-topped features interpreted as drowned carbonate terraces and platforms. Red lines and lettering correspond to dredgings. White boxe corresponds to the location of specific geomorphologies shown in figure $3 \mathrm{~B}$. The yellow star corresponds to a sea bottom picture presented in figure 8 . Black dashed lines and lettering correspond to the location of morphological cross-sections shown in figure 3C. fe: fault escarpments; mfs: margin failure scar. (B) Close up of volcanic cones 
morphology (C) Morphological cross-sections of Bassas da India terraces. The red star corresponds to the approximate location of DR20 dredge along morphological cross-section.

Figure4: (A) Overall geomorphology of the Hall Bank seamount (see location on figure 1B \& 1C). Green italic lettering corresponds to the nomenclature for successive flat-topped features interpreted as drowned carbonate terraces and platforms. Red lines and lettering correspond to dredgings. White boxes correspond to the location of specific geomorphologies shown in figure 4B, 4C \& 4D. The yellow star corresponds to a submarine picture shown in figure 8 . Black dashed lines and lettering correspond to the location of morphological cross-sections shown in figure 4E. fe: fault escarpment; mfs: margin failure scar.(B) Close up of rounded depressions interpreted as resulting from volcanic or karstic processes. (C) Close up of rugged, positive features along the $\mathrm{H} 2$ drowned carbonate terrace. This morphology is interpreted as resulting from submarine volcanic eruptions. The yellow star corresponds to an underwater picture shown in figure 8. (D) Close up of backstepping features interpreted as successive "backstepped" carbonate terraces. (E) Morphological cross-sections of Hall Bank margins. The red star corresponds to the approximate location of DR18 dredge along morphological cross-section.

Figure5: (A) Overall geomorphology of the Jaguar Bank seamount (see location on figure 1B \& 1C). The red box corresponds to the location of a specific morphologies shown in figure 5B. fe: fault escarpment; mfs: margin failure scar. This overall flat-topped feature, interpreted as a drowned carbonate platform, is characterized by a dense normal fault network delimiting several tilted blocs. Black dashed line and lettering correspond to the location of the morphological cross-section shown in figure 5C (B) Close up of a positive, rough and lobate, morphology interpreted as a submarine lava flow (see text for more details). (C) Morphological cross-sections of the Jaguar Bank. 
Figure6: (A) Overall geomorphology of the Sakalaves Platform (see location on figure 1B) interpreted as a drowned shallow-water carbonate platform. Red lines and lettering correspond to dredge sampling. ru. in green italic lettering locates a flat-topped level characterized by very rugged reliefs. The white box corresponds to the location of a specific morphology shown in figure 6B. Black dashed line and lettering correspond to the location of the morphological cross-section shown in figure 6C. fe: fault escarpment; mfs: margin failure scar (B) Close up of the very rough flat topped level located on the western part of the Sakalaves Platform. These dense network comprised of linear positive ridges and surrounding heaps is interpreted as an eroded volcanic dyke system (for more details see the text).The yellow stars correspond to the location of underwater pictures shown in figure 8 . (C) Morphological cross-sections of the Sakalaves Platform. The red star corresponds to the approximate location of DW04 dredge along morphological cross-section.

Figure7:(A) Overall geomorphology of the Glorieuses platform (see location on figure 1B). Green italic lettering corresponds to the nomenclature for successive flat-topped features interpreted as drowned carbonate terraces and platforms. No fault nor recent volcanic features are observed. The white box corresponds to the location of a specific morphology shown in figure 7B. mfs: margin failure scar.(B) Close up of the drowned carbonate platform G2 which occurs at 750m deep, northwest of the modern Glorieuses Platform. Red lines and lettering correspond to the location of dredgings. The yellow star corresponds to the location of sea bottom pictures shown in figure 8 .

Figure8:Sea bottom pictures. (A) Limestone slab along the northern flank of the Hall Bank (see location on figure 3A). (B) Limestone slab along the G2 drowned carbonate terrace, northwest of the Glorieuses Platform (see location on figure 7B). (C) Volcanic dyke at the top of the Sakalaves Platform (see location on figure 6B). (D) Pillow lavas at the top of the Sakalaves Platform (see location on figure 6B).(E) Very dark volcanic outcrops with well- 
developed fracturing network at the top of the Hall Bank (H2, see location on figure 4C).(F) Lobate submarine lava flow on top of the B1 drowned carbonate terrace (Bassas da India, see location on figure $3 \mathrm{~A})$.

Figure9: Thin sections micrographs. RA: Rodophyte Algae; Co: Coral; Ha: Halimeda algae; EF: Encrusting Foraminifera, Ech: Echinoids. DR18-01 (A, B, C): Burdigalian skeletal packstone with encrusted coral grains, Lepidocyclina brouweri Rutten (Lb) and Miogyspina regularia BouDagher-Fadel and Price (Mio). DW05-C1 (D): Late Messinian - Early Zanclean packstone of planktonic foraminifera typified by Sphaeroidinella dehiscens Parker and Jones (Sa), Globigerinoides quadrilobatus d'Orbigny (Gdes) and Globoquadrina dehiscens Chapman, Parr, and Collins (Gq). DR20-01 (E,F): Middle Miocene - Early Pliocene skeletal Packstone characterized by Cycloclypeus carpenteri Brady (Cc) and Orbulina suturalis d'Orbigny (Os). DR18-03 (G, H): Rupelian skeletal packstone of LBF with volcanic fragments (v); Lepidocyclina sp. (L), Daviesina sp. (Da) and Spiroclypeus vermicularis Tan Sin Hok (Sv). DW04-01 (I): Coralgal Boundsone. DW04-02 (J): Zanclean packstone of planktonic foraminifera typified by Sphaeroidinella subdehiscens Parker and Jones (Ss), Globoquadrina sp. and Orbulina universa d'Orbignyi (Ou). DN01 (K, L): Coralgal Boundstone with pockets of LBF packstones typified by Discocyclina sella d'Archiac (Di).

Figure10: Timing of major phases of shallow-water carbonate platform development and geodynamic activity along Mozambique channels seamounts during Cenozoic times.

Table1: : Table summarizing dating results, depositional textures, main composition and interpreted depositional environments of carbonate samples described and used in this study.

\section{Supplemental Data Captions}


832 Supplementary 1: Synthetic tab about strontitum isotopic stratigraphy (SIS) including 833 SR87/SR86 ratios, ages and associated errors.

834 Supplementary 2: Volcanic rock samples collected along rough isolates ridges of the 835 Mozambique Channel. DR17-05, DR19-03, DR13-01 \& DW05-01: Alkali mafic lava 836 fragments; DW05-01: heterogeneous volcanic breccia; DR04-22: trachy-andesite to trachyte 837 lava block 


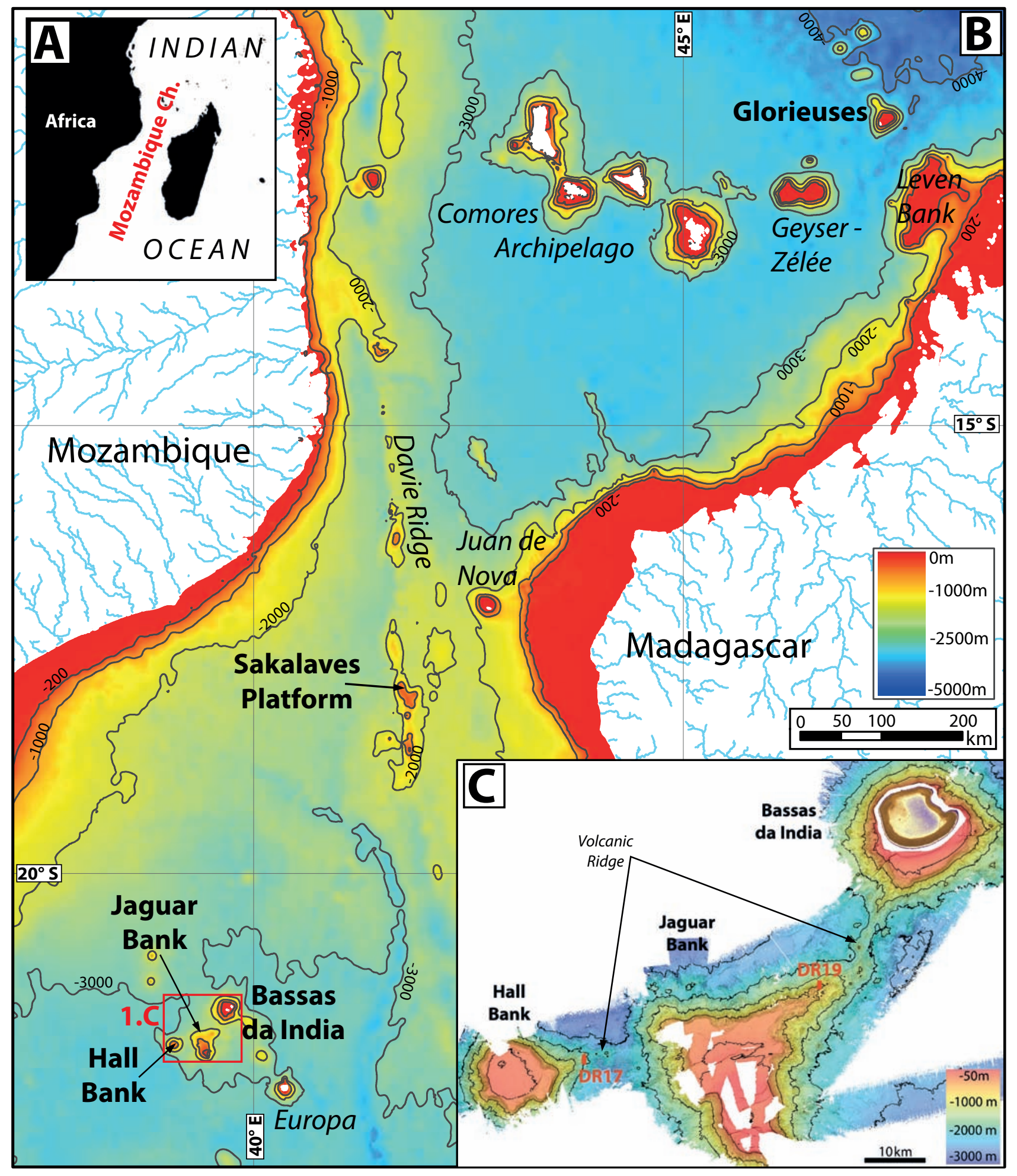




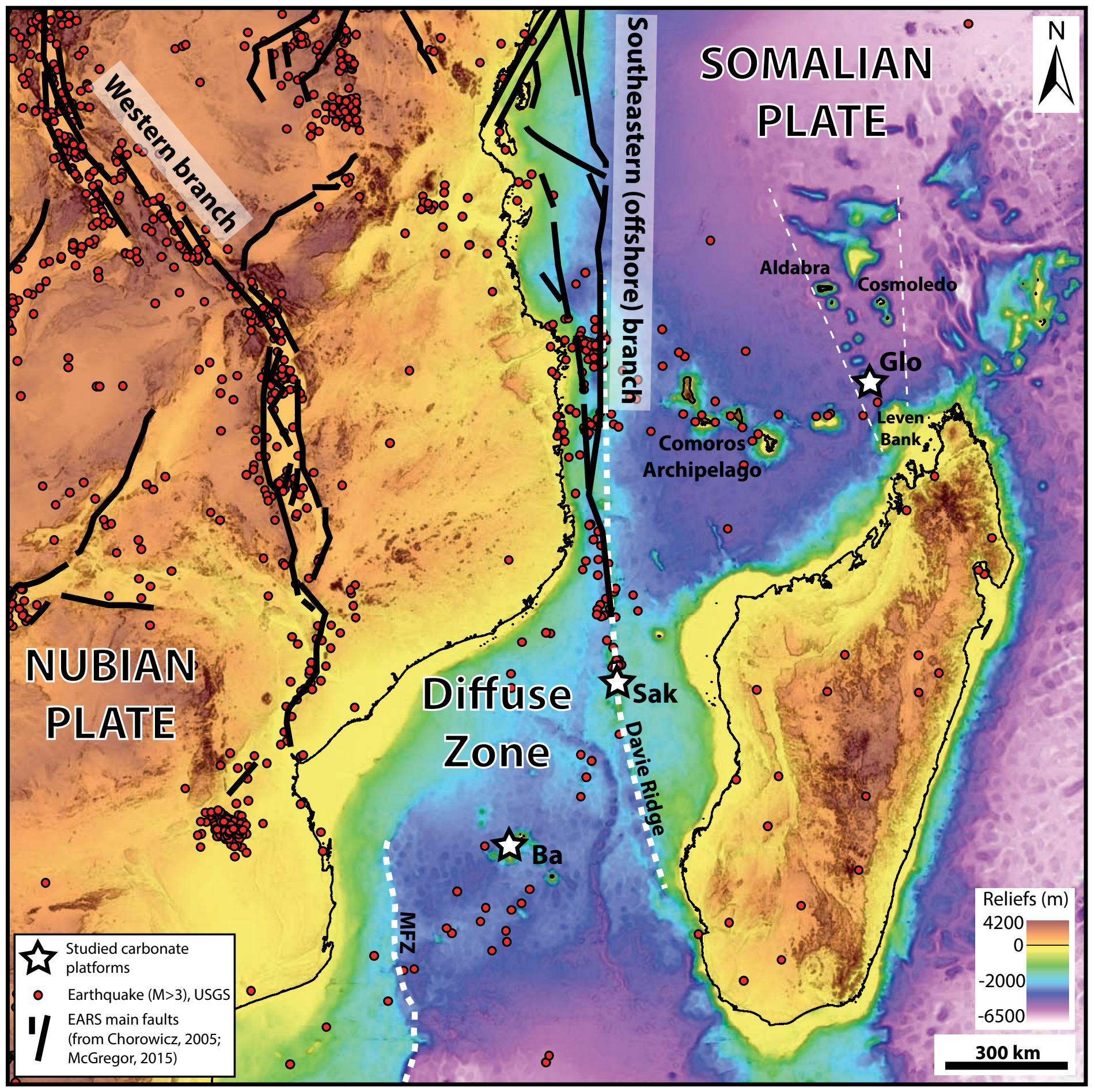



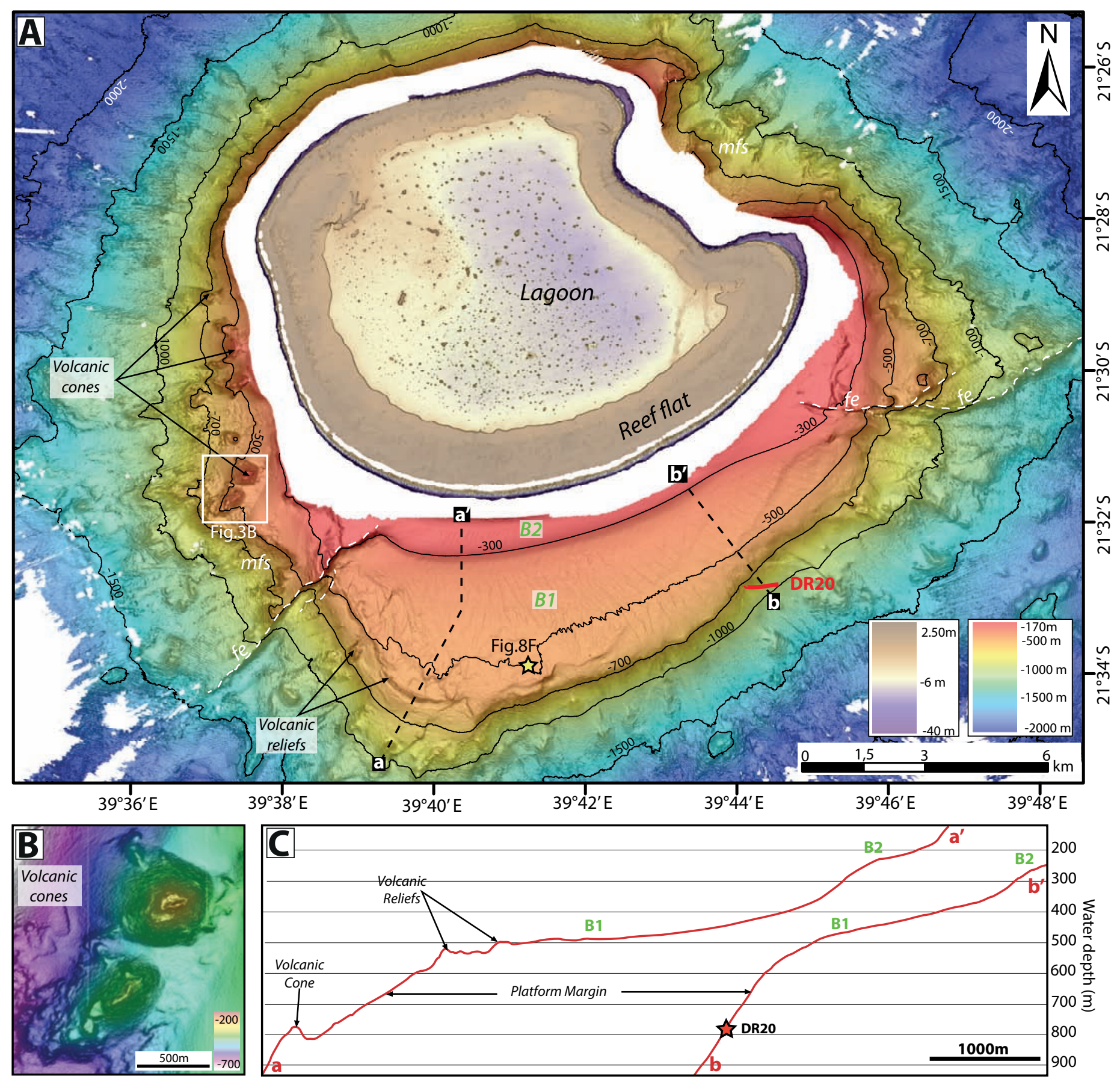


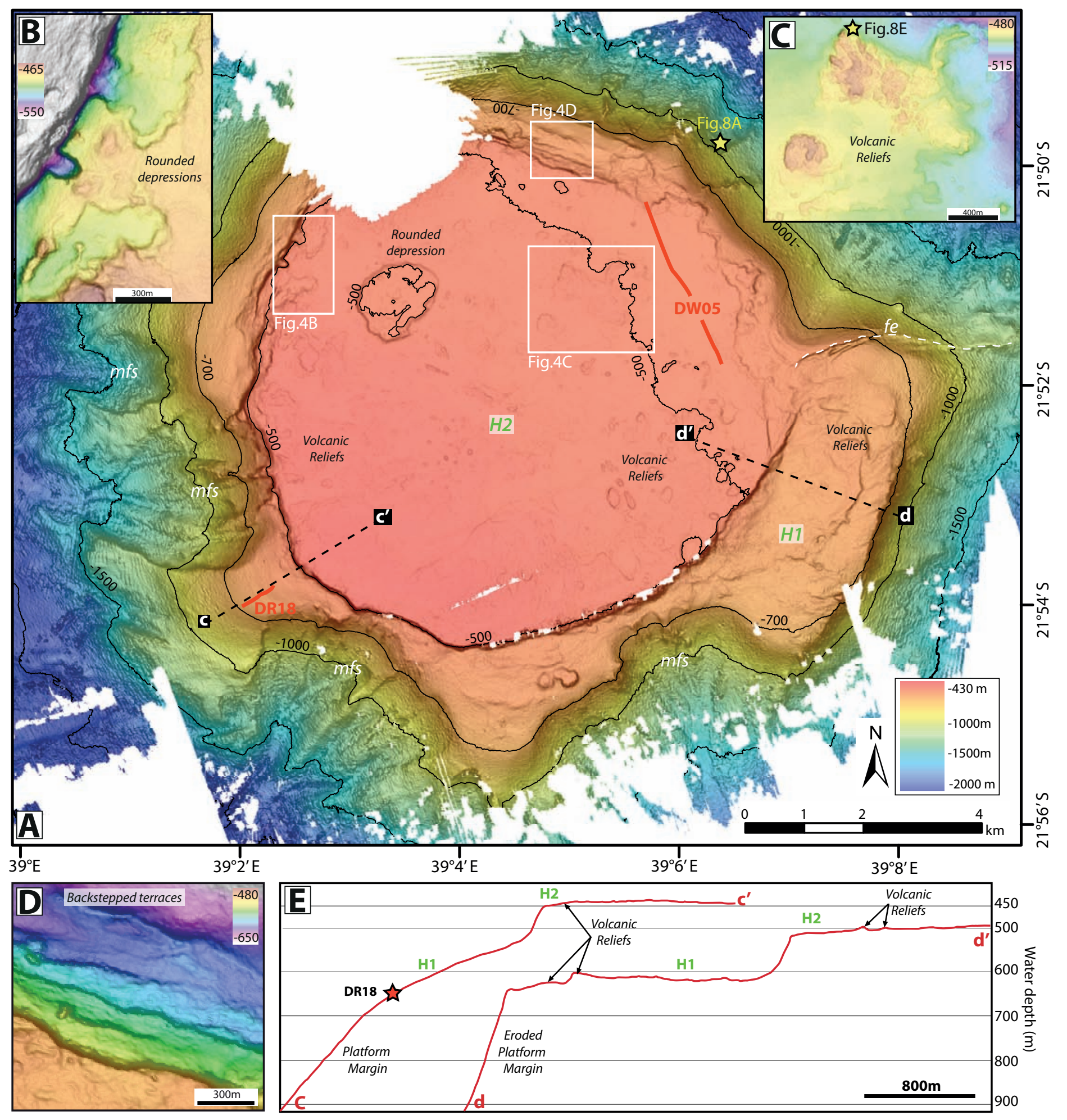




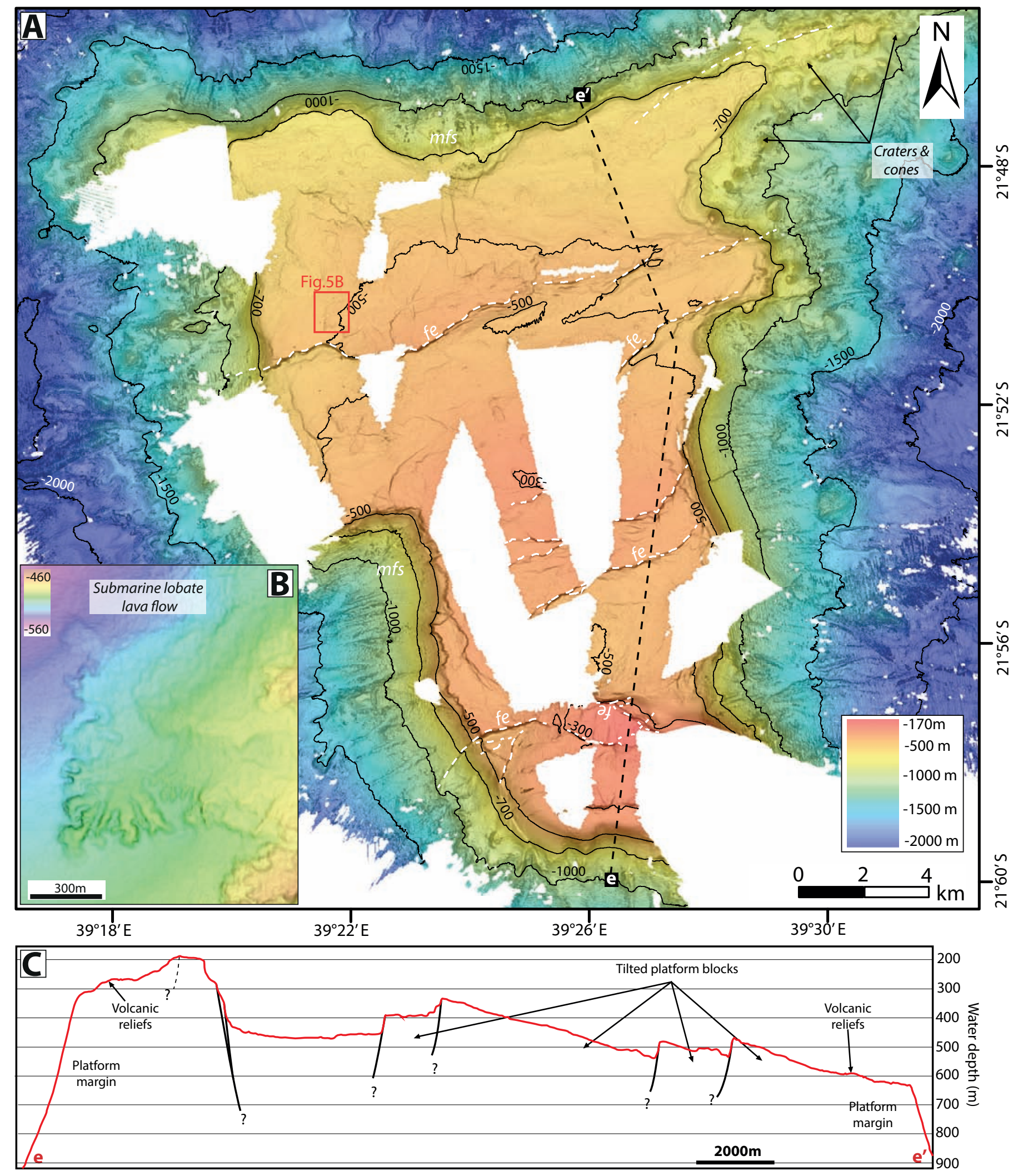




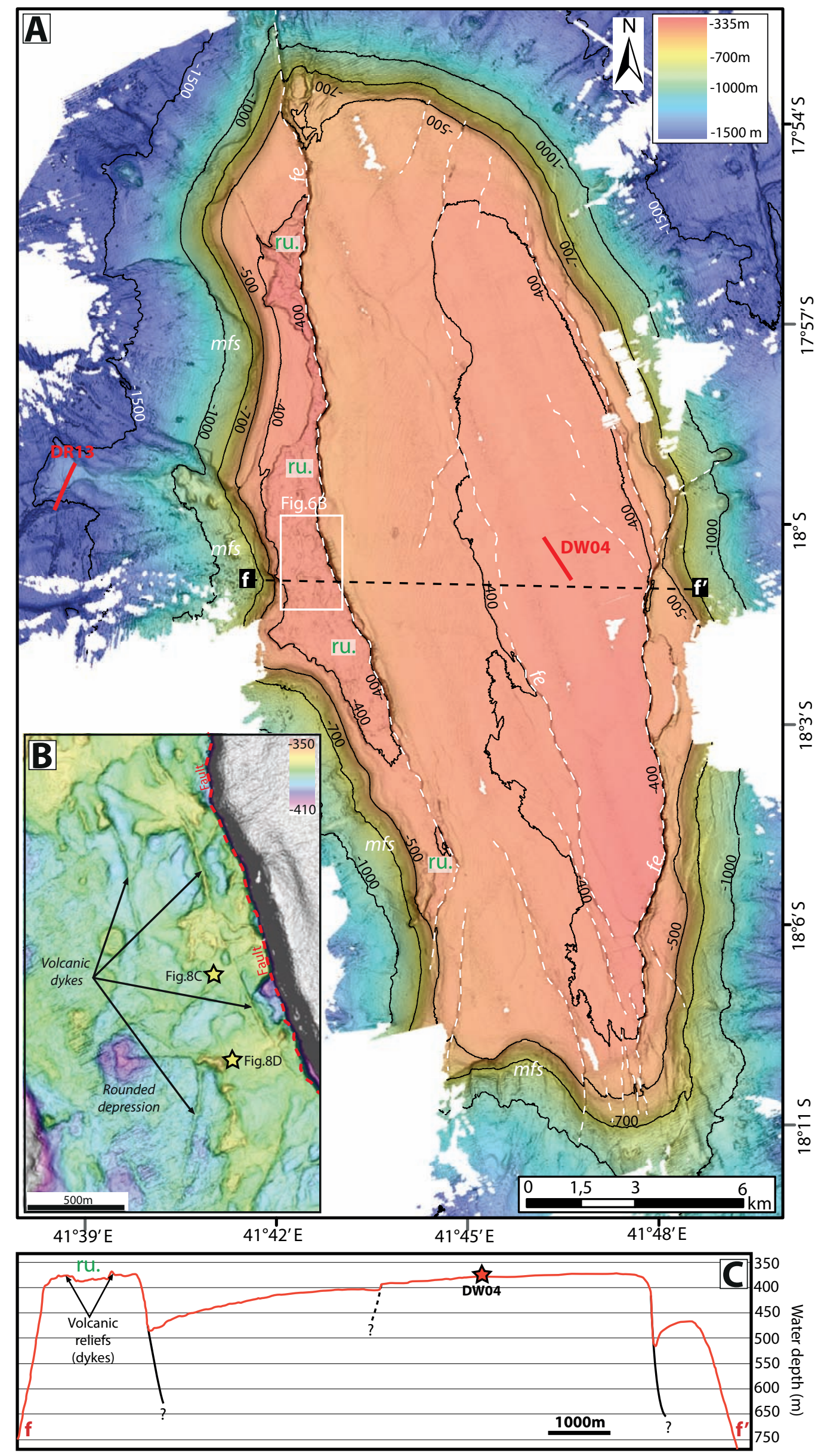




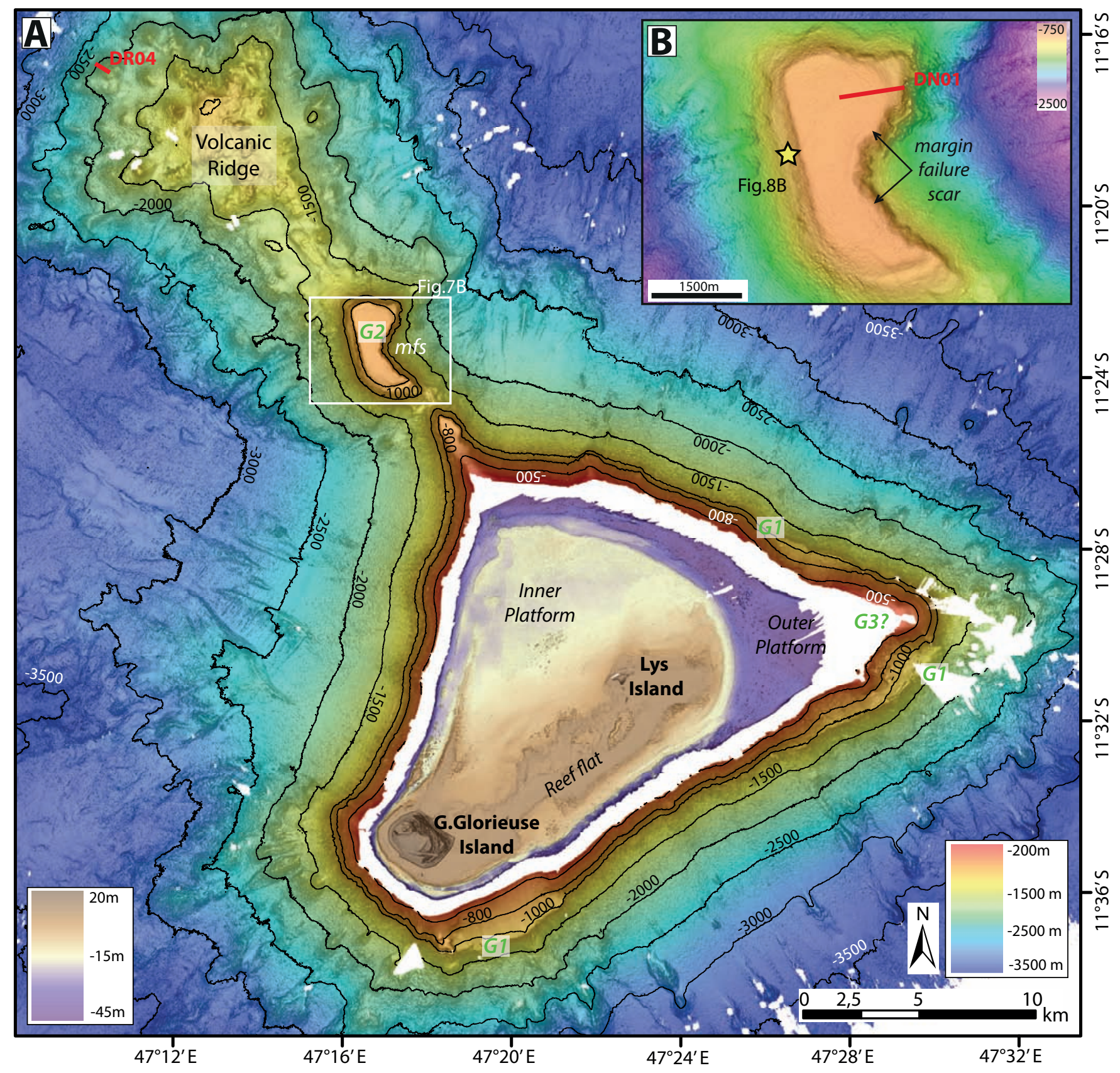




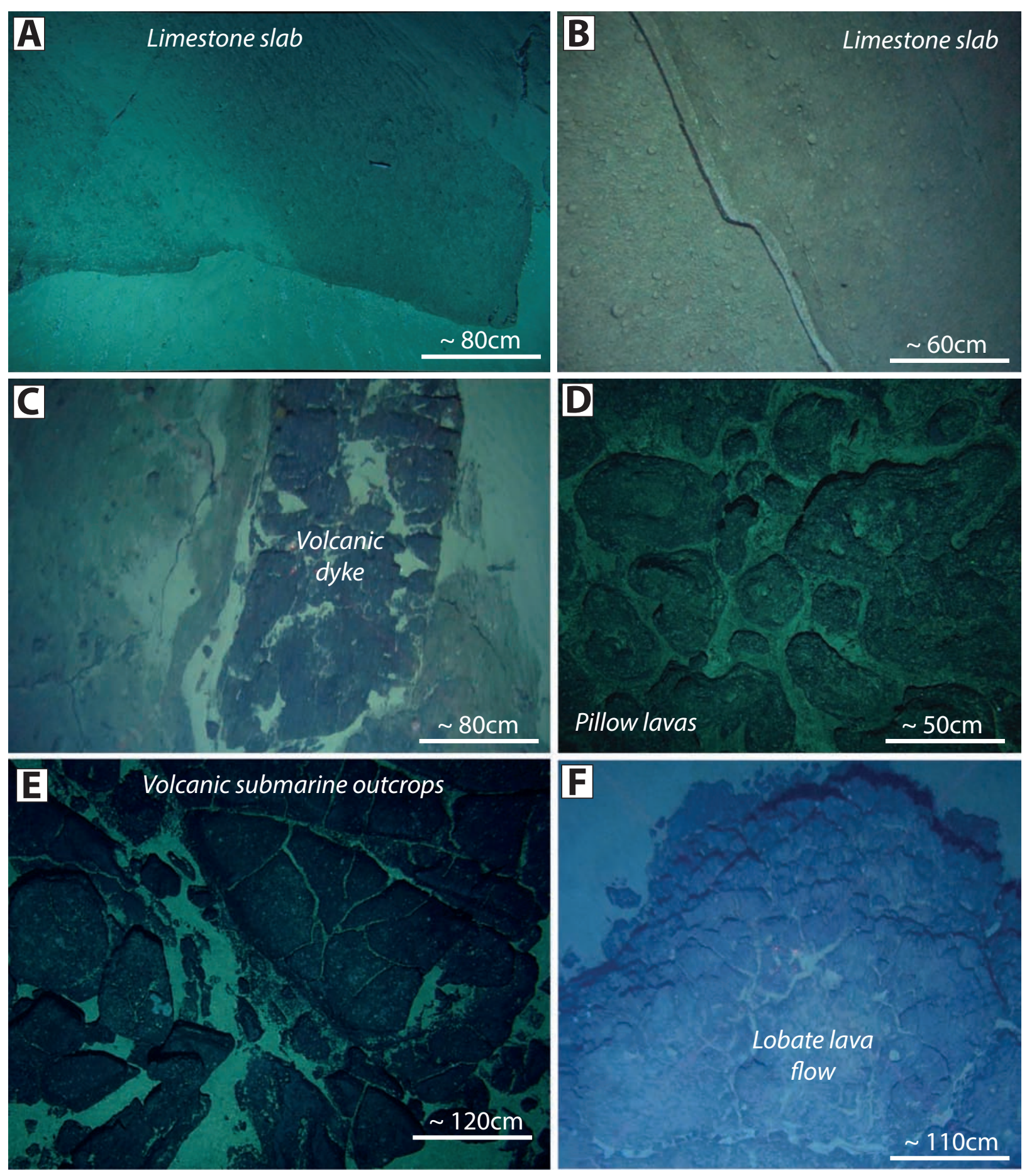




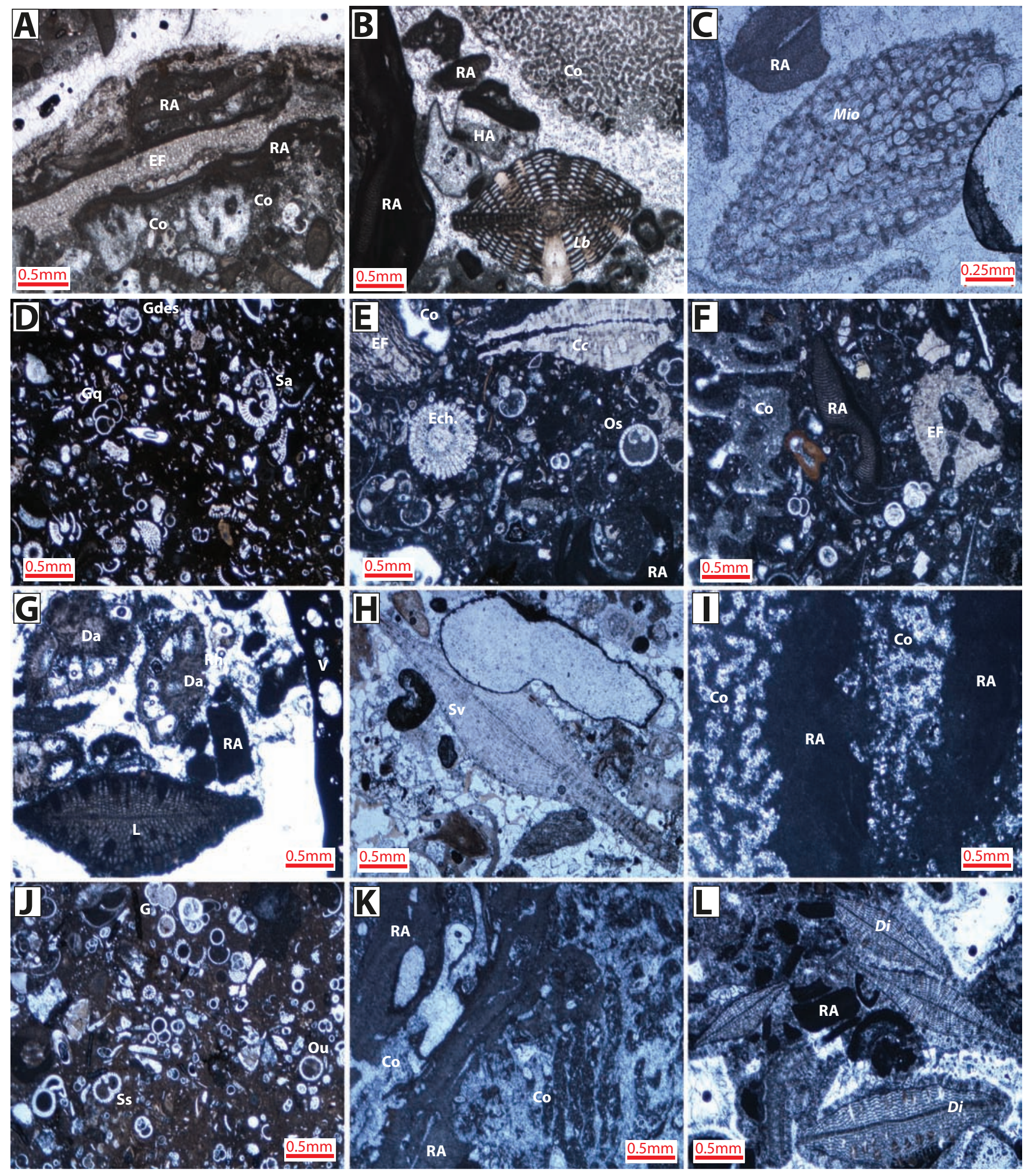




\begin{tabular}{|c|c|c|c|c|c|c|}
\hline Site & Sample & \begin{tabular}{|l} 
Age based on Foraminifera \\
first appearances. \\
Planktonic Foraminiferal zones, Shallow benthic zones \\
and letter stages after BouDagher-Fadel (2008, 2013 \& 2015)
\end{tabular} & $\begin{array}{l}\text { Age based on Strontium } \\
\text { Isotopic Stratigraphy (SIS) } \\
\text { Reference curve from McArthur (2012) }\end{array}$ & Depositionnal Texture & $\begin{array}{l}\text { Composition } \\
\text { Major components (in order of abundance) } \\
\text { Minor components }\end{array}$ & $\begin{array}{c}\text { Depositionnal } \\
\text { Environment }\end{array}$ \\
\hline \multirow{2}{*}{$\begin{array}{l}\text { Hall } \\
\text { Bank }\end{array}$} & $\begin{array}{l}\text { DR18 } \\
-01\end{array}$ & $\begin{array}{l}\text { N8a, 17-15.9 Ma, } \\
\text { Burdigalian ( Early Miocene) }\end{array}$ & $\begin{array}{c}16.29+/-0.10 \mathrm{Ma} \\
\text { Burdigalian (Early Miocene) }\end{array}$ & $\begin{array}{l}\text { Skeletal packstone with } \\
\text { encrusted coral grains }\end{array}$ & $\begin{array}{l}\text { Coral, Red Algae, LBF, Halimeda sp., EF } \\
\text { Echinoids, Bryozoans, Bivalves, Gastropods, PF }\end{array}$ & $\begin{array}{l}\text { Shallow-water } \\
\text { tropical platform }\end{array}$ \\
\hline & $\begin{array}{l}\text { DW05 } \\
-\mathrm{C} 1\end{array}$ & $\begin{array}{l}\text { N18-N19, 5.8 - 3.8 Ma, } \\
\text { Late Messinian - Early Zanclean }\end{array}$ & $\begin{array}{c}5.09+/-0.08 \mathrm{Ma} \\
\text { Zanclean (Early Pliocene) }\end{array}$ & $\begin{array}{l}\text { Packstone of planktonic } \\
\text { foraminifera }\end{array}$ & $\begin{array}{c}\text { PF } \\
\text { Echinoids, Bivalves, Gastropods }\end{array}$ & Outer Neritic/Pelagic \\
\hline $\begin{array}{l}\text { Bassas } \\
\text { da India }\end{array}$ & $\begin{array}{l}\text { DR20 } \\
-01\end{array}$ & $\begin{array}{l}\text { N9-N20a, } 15.0 \text { - 3.6 Ma, } \\
\text { Middle Miocene - Early Pliocene }\end{array}$ & $\begin{array}{l}8.48+/-0.49 \mathrm{Ma} \\
\text { Tortonian (Late Miocene) }\end{array}$ & Skeletal packstone & $\begin{array}{c}\text { PF, EF, Corals, Red Algae, LBF (some } \\
\text { reworked forms), bivalves } \\
\text { Echinoids, Gastropods, Bryozoans, Halimeda sp. }\end{array}$ & $\begin{array}{l}\text { Shallow-water } \\
\text { tropical platform }\end{array}$ \\
\hline \multirow{3}{*}{$\begin{array}{l}\text { Sakalaves } \\
\text { platform }\end{array}$} & $\begin{array}{l}\text { D13 } \\
-08\end{array}$ & $\begin{array}{l}\text { P18-P19, } 33.9-30.3 \mathrm{Ma}, \\
\text { Rupelian (Oligocene) }\end{array}$ & $\begin{array}{l}33.11+/-0.14 \mathrm{Ma}, \\
\text { Rupelian (Oligocene) }\end{array}$ & $\begin{array}{l}\text { Skeletal grainstone } \\
\text { of LBF with rodholith } \\
\text { fragments }\end{array}$ & $\begin{array}{l}\text { LBF, Red algae, Volcanic fragments, EF } \\
\text { Bivalves, Echinoids, Gastropods, } \\
\text { Bryozoans, Green algae }\end{array}$ & $\begin{array}{l}\text { Shallow-water } \\
\text { tropical platform }\end{array}$ \\
\hline & $\begin{array}{l}\text { DW04 } \\
-01\end{array}$ & $\begin{array}{l}\text { N14-N21, } 11.6-1.6 \mathrm{Ma}, \\
\text { Late Miocene- Pleistocene }\end{array}$ & $\begin{array}{l}8.80+/-0.35 \mathrm{Ma} \\
\text { Tortonian (Late Miocene) }\end{array}$ & $\begin{array}{c}\text { Coralgal } \\
\text { boundstone }\end{array}$ & $\begin{array}{l}\text { Coral, Red algae } \\
\text { LBF, Gastropods }\end{array}$ & $\begin{array}{l}\text { Shallow-water } \\
\text { tropical platform }\end{array}$ \\
\hline & $\begin{array}{l}\text { DW04- } \\
02 a\end{array}$ & $\begin{array}{c}\text { N19-N20, 5.3 - 3.4 Ma, } \\
\text { Zanclean (Early Pliocene) }\end{array}$ & No data & $\begin{array}{l}\text { Packstone of planktonic } \\
\text { foraminifera }\end{array}$ & $\begin{array}{c}\mathrm{PF} \\
\text { Bivalves, Echinoids, Gastropods, SBF }\end{array}$ & Outer Neritic/Pelagic \\
\hline Glorieuses & $\begin{array}{l}\text { DN01 } \\
-01\end{array}$ & $\begin{array}{c}\text { P3-P5a, } 61.6-56.0 \mathrm{Ma} \\
\text { Selandian - Thanetian (Paleocene) }\end{array}$ & $\begin{array}{l}61.52+/-1.80 \mathrm{Ma}^{*} \\
\text { Selandian (Paleocene) }\end{array}$ & $\begin{array}{l}\text { Coralgal boundstone with } \\
\text { pockets of LBF packstone }\end{array}$ & $\begin{array}{l}\text { Red algae, LBF, Coral, EF } \\
\text { Bryozoans, Echinoids, Bivalves, } \\
\text { Gastropods, SBF, PF }\end{array}$ & $\begin{array}{l}\text { Shallow-water } \\
\text { tropical platform }\end{array}$ \\
\hline
\end{tabular}

*(or 33.89 +/- 0.15 Ma or 67.11 +/- 0.27 Ma) LBF: Large Benthic Foraminifera; SBF: Small Benthic Foraminifera; EF: Encrusting Foraminifera; PF: Planktonic Foraminifera 


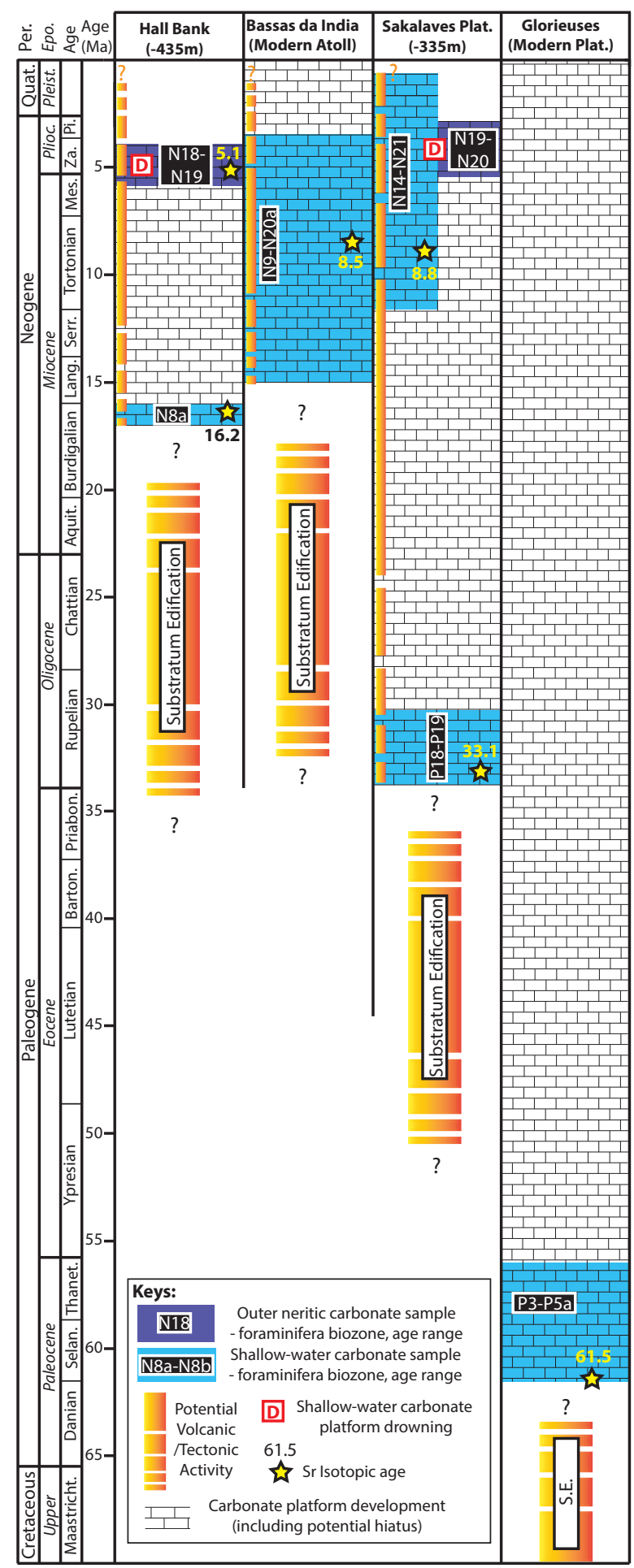




\begin{tabular}{|c|c|c|c|c|}
\multicolumn{1}{c}{ Sample } & \multicolumn{1}{c}{${ }^{87} \mathrm{Sr} /{ }^{86} \mathrm{Sr}$} & 1 sigma error & Age $(\mathrm{Ma})$ & \multicolumn{1}{c}{ /- (Ma) } \\
\hline DR18-01 & 0.708702 & 0.000003 & 16.29 & 0.10 \\
\hline DW05-C1 & 0.709033 & 0.000005 & 5.09 & 0.08 \\
\hline DR20-01 & 0.708927 & 0.000003 & 8.48 & 0.49 \\
\hline D13-08 & 0.707856 & 0.000004 & 33.11 & 0.14 \\
\hline DW04-01 & 0.708921 & 0.000008 & 8.80 & 0.35 \\
\hline & & & 33.89 & 0.15 \\
\hline DN0-01 & 0.707812 & 0.000003 & 61.52 & 1.80 \\
\cline { 4 - 6 } & & & 67.11 & 0.27 \\
\hline
\end{tabular}

Supplementary 1 

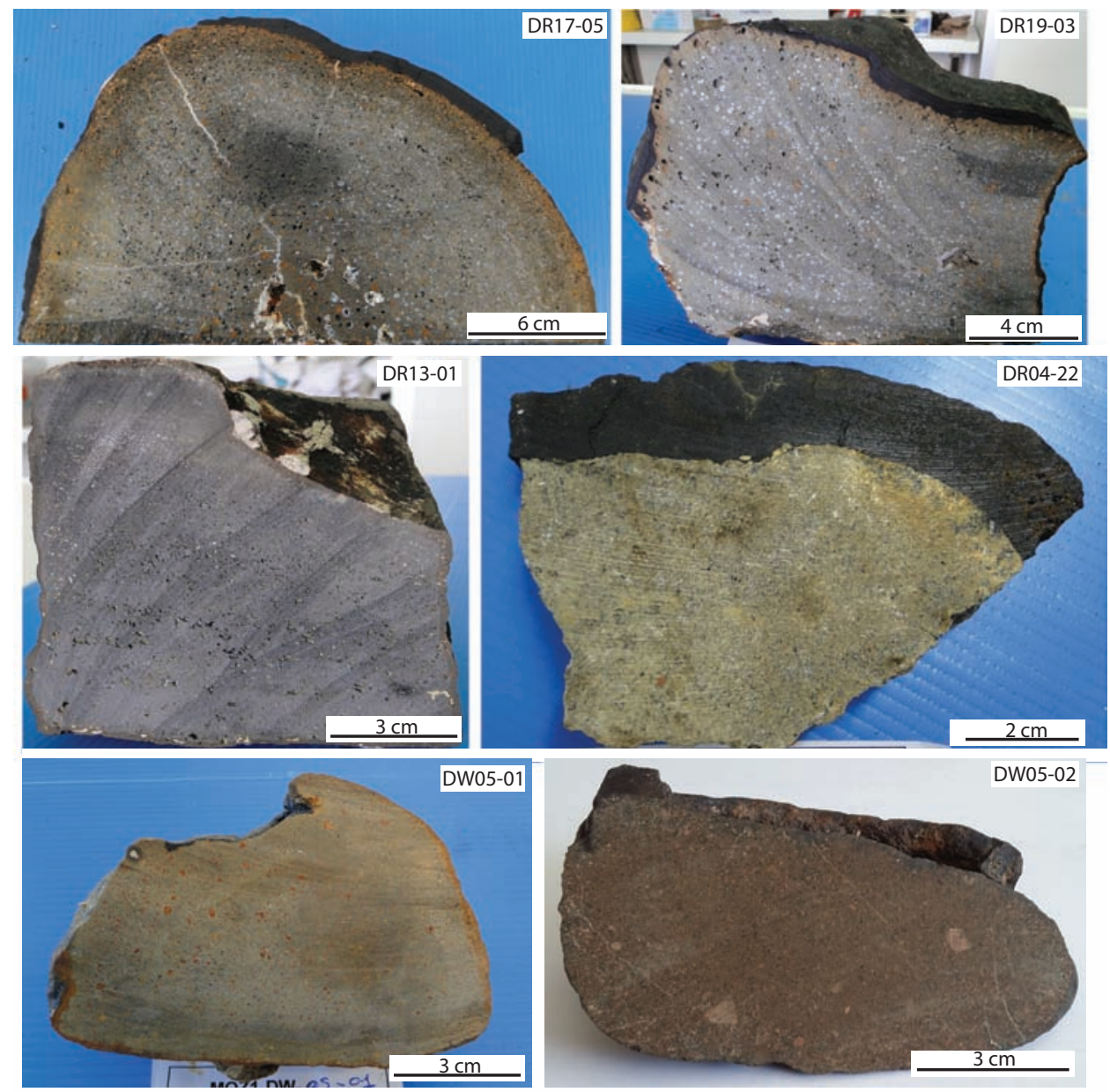

Supplementary 2 